\title{
Uppermost Ordovician bivalves from the Prague Basin (Hirnantian, Perunica, Bohemia)
}

\author{
JIŘí KŘIZŽ \& MARIKA STEINOVÁ
}

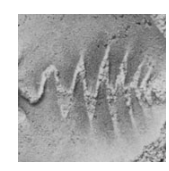

\begin{abstract}
Twelve species (four new) and 9 genera of bivalves are described from the uppermost Hirnantian, Upper Ordovician of the Prague Basin, Bohemia: Praenucula dispar (Barrande, 1881), Praenucula abrupta sp. nov., Sluha kosoviensis (Barrande, 1881), Nuculites aff. planulatus Conrad, 1841, Myoplusia contrastans (Barrande, 1881), Myoplusia obtusa (Barrande, 1881), Myoplusia sp., Metapalaeoneilo dromon sp. nov., Praeleda compar (Barrande, 1881), Mytilarca mareki sp. nov., Modiolopsis pragensis sp. nov., and ?Sphenolium cf. parallelum Ulrich, 1894. From the coarse, storm generated sandstones representing the additional regressive event, when the shelf was channelled, and coarse material transported from the shore in the late Hirnantian, the low diversified, almost monospecific Modiolopsis pragensis Community, of the Modiolopsis Community Group, was described. It indicates restricted living conditions. 11 bivalve species form, together with 25 species of brachiopods, 5 species of gastropods, and undescribed conulariids, hexactinellids, trepostomate bryozoans, annelids, hyolithids, orthocone nautiloids, rare ostracods, phyllocarids, blastoids, cystoids, crinoids, dendroids, graptolites, and chlorophytes (receptaculitids) the redefined Hirnantia sagittifera-Sluha kosoviensis Community. It represents the most diversified community of the Hirnantia Community Group known in the World. We suppose that the Hirnantia sagittifera-Sluha kosoviensis Community occupied the well-ventilated environment of the soft bottom carbonate silts with high organic content. The community was most probably autochthonous, with minimal transport as is indicated by the common preservation of shells with conjoined valves (articulate brachiopods, semi-infaunal bivalve Mytilarca mareki, and infaunal bivalves). The bivalves Mytilarca mareki and Metapalaeoneilo dromon sp. nov., Nuculites aff. planulatus, and ?Sphenolium cf. parallelum may have originated in the Baltica carbonate platforms and the equatorial regions of Avalonia and Laurentia and support the ideas about the position of the Kosov Province in the temperate-to-subtropical zone (between $30^{\circ}$ to $45^{\circ} \mathrm{S}$ ). For the analogous and homologous communities we described the Hirnantia Community Group as a substitute for the term "Hirnantia fauna". The Hirnantia Community Group was most probably extending from the circumpolar sphere into the temperate to tropical zones in proximity to the carbonate platforms. In Bohemia and elsewhere it occurs just a few metres below the Ordovician-Silurian boundary and represents the evidence of the environmental recovery during the uppermost Ordovician transgression following the Upper Ordovician global glaciation. $\bullet$ Key words: Bivalvia, uppermost Ordovician, late Hirnantian, systematics, palaeoecology, Perunica, Prague Basin, Bohemia.
\end{abstract}

KŘíž, J. \& STEInOVÁ, M. 2009. Uppermost Ordovician bivalves from the Prague Basin (Hirnantian, Perunica, Bohemia). Bulletin of Geosciences 84(3), 409-436 (9 figures, 1 table). Czech Geological Survey, Prague. ISSN 1214-1119. Manuscript received April 27, 2009; accepted in revised form June 5, 2009; published online August 14, 2009; issued September 11, 2009.

Jiři Kř̌̌, Czech Geological Survey, P.O. Box 85, Praha 011, Czech Republic; jiri.kriz@geology.cz・Marika Steinová, Czech Geological Survey, P.O. Box 85, Praha 011, Czech Republic; marika.steinova@ geology.cz

The Kosov Formation (Hirnantian, Ordovician) reflects in the Prague Basin, Bohemia a remote global large-scale Gondwanan glaciation, glacial regressions, post-glacial transgressions and related biodiversity changes in the midto outer-shelf settings (Brenchley \& Štorch 1989; Štorch 1986a, 2006). From alternating shale and sandstone beds in the middle parts of the Kosov Formation Mikuláš (1992) described numerous ichnogenera and assigned them to the shallow-water Cruziana Ichnofacies or Nereites Facies. The rhythmically bedded unit is terminated by the clayey shale and siltstones with inferior sandy intercalations.
The upper part of the Kosov Formation is developed as the banks of glacial regressive (Štorch 1986a) ill-sorted, coarse-grained pebbly sandstone and fine-grained conglomerate (Havlíček 1950, 1998) with rare ichnofauna (Mikuláš 1992). In the eastern parts of the Prague Basin (Tachlovice, Praha-Nová Ves, Praha-Hodkovičky, Praha-Běchovice a.o.) the almost monospecific Modiolopsis pragensis Community known already to Barrande (1881), accompanied by rare brachiopods, rostroconchids, gastropods, Cornulites sp. and trilobites (Marek \& Havlíček 1967, Havlíček 1987) is characteristic. 

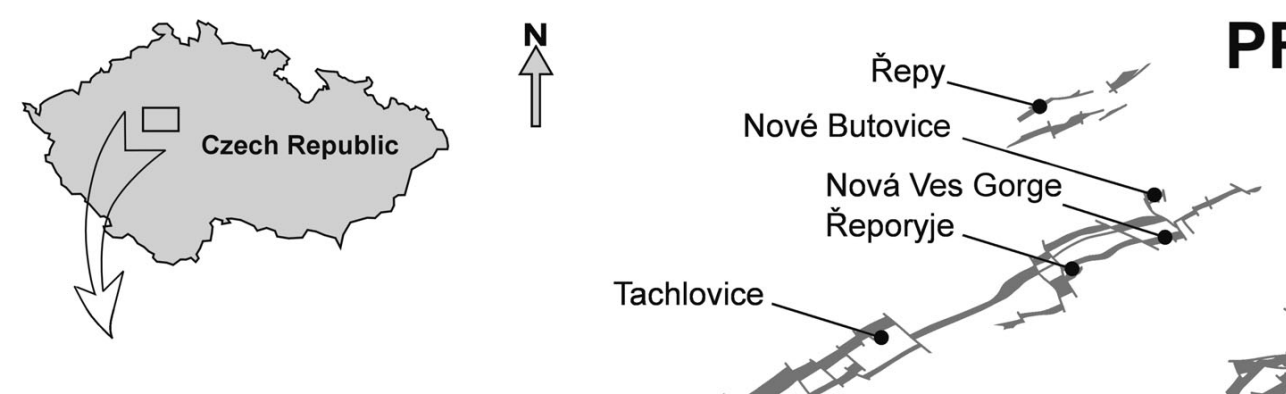

PRAHA
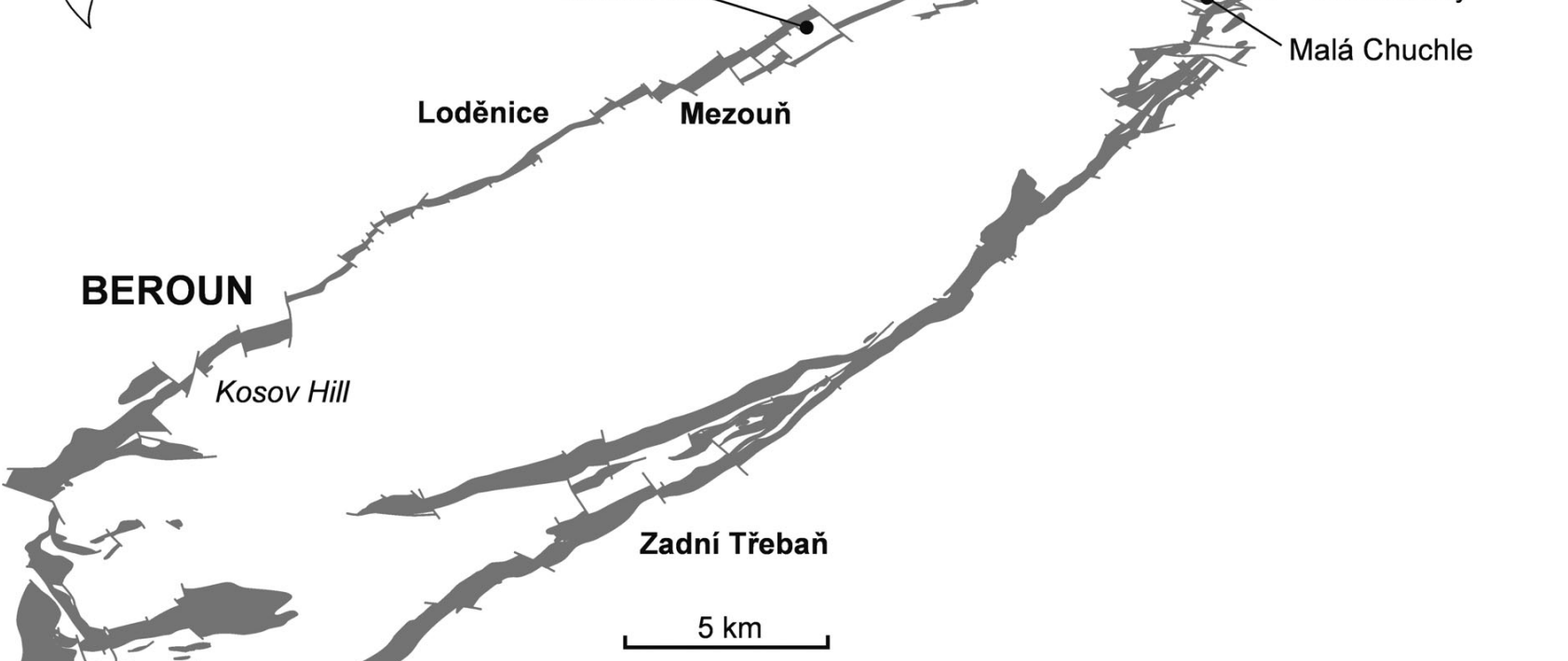

Libomyšı

Figure 1. Distribution of the Hirnantian rocks in the Prague Basin and the location of the localities discussed in the text.

The uppermost part of the Kosov Formation in the eastern part of the Prague Basin (Praha-Běchovice locality, Marek 1963b; Praha- ̌̌eporyje, Kř́iž in Štorch 1986b; Tachlovice, Prantl \& Přibyl 1944 a.o.) is developed as a post-glacial transgressive grey micaceous shale with flat nodules of decalcified light grey siltstone. In the highest part of this unit at the locality Praha-Nové Butovice were recorded by Mikuláš (1992) very strong bioturbation (Planolites and Arenicolites). The siltstone nodules contain the Hirnantia sagittifera-Sluha kosoviensis Community dominated by the brachiopods Kinnella kielanae proclinis Havlíček, 1977 and Dalmanella testudinaria (Dalman, 1828) and composed of 23 other species of brachiopods (Marek \& Havlíček 1967; Havlíček 1977, 1987, 1994, 1998) accompanied by conulariids, hexactinellids, annelids, bryozoans, hyolithids, bivalves, gastropods, orthocone nautiloids, trilobites, bryozoans, ostracods, phyllocarids, blastoids, cystoids and crinoids, graptolites, dendroids, and chlorophytes (Marek 1963a, b; Havlíček 1987).

The research of the Hirnantian in the Prague Basin has a long tradition started already by Barrande (1881) who first described from the upper Hirnantian sandstones in the vicinity of Prague (Tachlovice and Praha-Hodkovičky localities) bivalve Modiolopsis draboviensis (= Modiolopsis pragensis sp. nov.). In 1943 Prantl (Prantl \& Přribyl 1944) discovered in the Tachlovice borehole the uppermost
Hirnantian shales with limestone nodules and layers with a graptolite fauna (Normalograptus sp.) and the trilobite Brongniartella sp. In the vicinity of Úvaly (east of Prague), north of Běchovice village, Havlíček mapped at the end of first half of the last century poorly exposed shallow syncline comprising the Kosov Formation (Hirnantian) and the lowermost Silurian Želkovice Formation (Havlíček 1950). He described here the high Kosov Formation coarse sandstone beds (up to $30 \mathrm{~cm}$ thick) and levels of clayey shale with the trilobite Brongniartella platynota (Dalman, 1828).

Very important are the studies of late Ladislav Marek (1928-1995) from the Academy of Sciences, Czechoslovakia, who systematically searched for the fossiliferous latest Ordovician rocks in the Prague Basin. In 1950 he discovered and exposed in Nová Ves Gorge near Praha-Butovice (Marek 1951) upper parts of the Kosov Formation (uppermost Hirnantian). In $140 \mathrm{~cm}$ thick bank of the coarse grained sandstone he found internal moulds of Modiolopsis sp. (= Modiolopsis pragensis sp. nov.) and Brongniartella sp. The bank is overlain by a few metres of grey green thin-bedded clayey and micaceous shale with Normalograptus sp., brachiopods of the Hirnantia Community (Marek \& Havlíček 1967), trilobites, bivalves, bryozoans, crinoids and sponge spicules.

The most important locality with the uppermost Ordovician fauna occurrence north of Praha-Běchovice was dis- 
covered by Marek at the end of 1961 (Marek 1963b). He collected here, in the level with flat lenses and nodules of decalcified clayey siltstone, a well-preserved fauna representing 16 classes of organisms. The most common are the brachiopods of the Hirnantia Community (Marek \& Havlíček 1967), bivalves, gastropods, trilobites, graptolites, crinoids and bryozoans. Marek (1963a) systematically described bellerophontid gastropods, and Havlíček (1994) inarticulate brachiopods from this locality.

Marek \& Havlíček in 1967 described detailed section of the Praha-Běchovice locality. The upper Kosov Formation (Hirnantian) consists of predominant pelites with the intercalations and beds of light-coloured quartz sandstone and quartzite. In the higher Kosov Formation the light-coloured mostly coarse-grained sandstone of unknown thickness is developed. It splits readily into thin laminae. By far the most prevalent fossil is Modiolopsis pragensis and different ontogenetic stages are represented, but adult single valves are the most common and frequently cover the bedding planes.

The sandstone is overlain by ash-grey clayey micaceous shale representing the uppermost Ordovician sediments just below the Silurian (Llandovery). Their thickness was estimated at 5-10 m. In the shale were found deformed trilobite Mucronaspis mucronata (Brongniart, 1822), brachiopods Dalmanella testudinaria (Dalman, 1828), Rafinesquina sp. and Elegantilites sp. The shale contains the level of a large flat lenses and nodules of light-grey decalcified, slightly clayey compact siltstone. The largest nodule found was $60 \mathrm{~cm}$ in diameter and about $10 \mathrm{~cm}$ thick. The nodules are crowded with the perfectly preserved specimens of the highly diversified Hirnantia sagittifera Community (several tens of species), especially brachiopods and molluscs (Havlíček 1982).

Štorch (Štorch 1980, 1982, 1986a, b, 1988, 1990, 2006; Štorch \& Loydell 1996; Brenchley \& Štorch 1989; Brenchley et al. 1991) paid during the last three decades extensive attention to the Ordovician and Silurian boundary rocks and fossils in the Prague Basin. He discovered several new uppermost Ordovician fossiliferous localities (temporary outcrops in Praha-̌̌epy area, Praha-ŘReporyje, Praha-Velká Ohrada and Praha-Nové Butovice area, and Loděnice-Mezouň area). In 1980 Štorch mentioned and figured bivalves from the Repy area temporary outcrops [Cyrtodonta sp. 1 and Cyrtodonta sp. 2 (= Mytilarca mareki sp. nov.)].

\section{Systematic palaeontology}

Abbreviations. $-\mathrm{V}=$ valve, $\mathrm{L}=$ length of the shell, $\mathrm{H}=$ height of the shell, $\mathrm{W}=$ width of the shell, $\mathrm{W} / 2$ = width of one valve (Kříž 1969); JK 14 931-JK 15114 (181 specimens) deposited in the collection of Jiři Kř́ž in the Czech

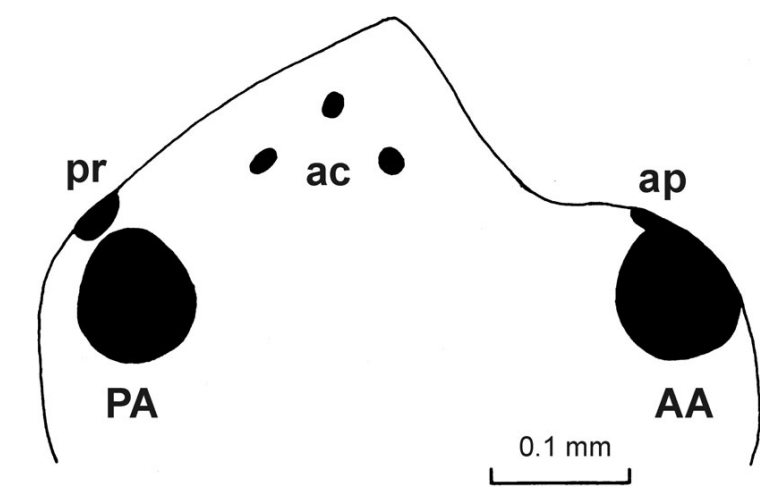

Figure 2. Diagrammatic side view showing the position of principal and accessory musculature of Praenucula dispar (Barrande, 1881). Key to letter symbols: PA - posterior adductor muscle scar; AA - anterior adductor muscle scar; $\mathrm{pr}$ - posterior retractor muscle scar; ap - anterior protractor muscle scar; ac - accessory muscle scars.

Geological Survey, Prague; NM bivalves deposited in the National Museum, Prague. All measurements are in millimetres.

Class Bivalvia Linné, 1758

Subclass Protobranchia Korobkov, 1954

Order Nuculoida Dall, 1889

Superfamily Nuculoidea Gray, 1824

Family Praenuculidae McAlester, 1969

\section{Genus Praenucula Pfab, 1934}

Type species. - Praenucula dispar expansa Pfab, 1934, Praenucula dispar (Barrande, 1881) = senior synonym. Bohemia, Prague Basin, Osek, Middle Ordovician, Darriwilian, Šárka Formation.

Remarks. - Pfab (1934) described two genera Praenucula and Praeleda, very similar in general shape. McAlester (1968, 1969) revised the type material of these two genera and included Praeleda into the synonymy of Deceptrix Fuchs, 1919. McAlester (1969) showed that Praenucula differs from Deceptrix by the anterior and posterior teeth similar in the size and number. Bradshaw (1971) was of the opinion, that Praeleda is valid and that it could be an ancestor of Deceptrix. Tunnicliff (1982) supposed that Praeleda is the synonym of Deceptrix. Tunnicliff (1982) also described the main features of Deceptrix (in his concept) and Praenucula: 1) the posterior teeth in Deceptrix are smaller and more numerous than anterior teeth while in Praenucula the posterior and anterior teeth are similar in the size and number; 2) umbones in Praenucula lie in the posterior half while in Deceptrix they generally lie in anterior half; 3) in Deceptrix the adductor muscle scars are larger and in more ventral position, in Praenucula close to dorsal margin. Babin \& Gutiérrez-Marco (1991) were of the same opinion. 
To the contrary Cope $(1997,1999)$ proposed that genus Praeleda is valid and described the main features of Praeleda and Praenucula: 1) the umbones in Praenucula lie in the posterior half of the shell, in Praeleda the umbones are or in the posterior half of the shell, or in the central position; 2) in Praenucula the hinge plate has an approximately equal number of teeth in the anterior and posterior part of the hinge or, in some species, the number of the teeth in the anterior is higher than in the posterior. The anterior teeth may differ little in size from the posterior teeth, or may be markedly larger. The hinge axis is parallel to the dorsal margin and formed by both, the anterior and posterior dentition.

\section{Praenucula dispar (Barrande, 1881)}

Figures 2, 3C, D, I, J

1881 Nucula dispar Barr.; Barrande, pl. 273, figs VII/1-8, 13-16.

1934 Praenucula dispar dispar (n. var.); Pfab, pp. 235-236, pl. I, fig. 3c.

1934 Praenucula dispar expansa (n. var.); Pfab; pp. 235, pl. I, fig. 3d, pl. III, figs 10, 11, 15a, b.

1968 Praenucula expansa Pfab. - McAlester, pp. 46, 47, pl. 8, figs 3-9.

Lectotype. - Internal mould of the shell with conjoined valves, figured by Barrande (1881) on pl. 273, as figs VII/1-4, NM L 27176. Designed by Pfab (1934).

Paralectotypes. - Internal moulds of the shells with conjoined valves, figured by Barrande (1881) on pl. 273, as figs VII/ 5-7, and VII/8, NM L27177 and L27 178.

Type locality. - Bohemia, Prague Basin, Osek near Rokycany.

Type horizon. - Middle Ordovician, Darriwilian, Šárka Formation.

Material. - One right valve, one left valve from Praha-Běchovice.

Diagnosis. - Praenucula with slightly elongated anterior part of the shell, with convex anterior part of the dorsal margin and with three pairs of rounded accessory muscle scars in the posterior part of the shell.

Description. - Shell small, equivalve, inequilateral, and broadly ovate. Anterior part of the shell is larger than the posterior part. Anterior and posterior margins evenly rounded, ventral margin convex. Umbones located in the posterior half of the shell, prosogyrate. Inner surface sculpture is smooth. Hinge taxodont, teeth row continuous in the umbonal region. Posterior part of the hinge is with the convex teeth (6-8 in number). In umbonal part the teeth are becaming smaller and toward the anterior slightly larger and of the orthomorph shape (according to Babin 1966, p. 39). In anterior part of the hinge are 5-6 teeth. Anterior and posterior adductor muscle scars rounded, posteriorly from the anterior adductor muscle scars one pair of the pedal muscle scars (protractors) and anteriorly from the posterior adductor muscle scars one pair of the rounded pedal muscle scars (retractors) are developed. Posteriorly from the umbo (but still in the umbonal region) three pairs of rounded accessory muscle scars are impressed (Fig. 2). Outer surface sculpture and the shell thickness are unknown.

$\begin{array}{llrrr}\begin{array}{l}\text { Dimensions. }- \\ \text { specimen }\end{array} & \text { V } & \text { L } & \text { H } & \text { W/2 } \\ \text { NM L27176 } & \text { A } & 4.6 & 3.8 & 1.6 \\ \text { JK 14931 } & \text { R } & 5.9 & 5.8 & 3.1 \\ \text { NM L27177 } & \text { A } & 6.25 & 5.3 & 1.9 \\ \text { NM L27178 } & \text { A } & 8.1 & - & 3.1 \\ \text { JK 14943 } & \text { L } & 8.4 & 8.6 & 3.2\end{array}$

Discussion. - Pfab (1934) described Praenucula dispar expansa, which he designated as the type species of Praenucula Pfab, 1934. It differs from the nominotypical subspecies only by reduced one orthomorph tooth under the umbo. We do not consider this to be so important feature to distinguish a new subspecies occurring at the same locality as the nominotypical subspecies. Praenucula dispar differs from Praenucula abrupta sp. nov., in more broadly ovate than triangular shape and by convex anterior dorsal margin. Praenucula sharpei Babin \& Gutiérrez-Marco, 1991 from the Middle Ordovician of Spain has a more elongated anterior part of the shell. Praenucula mayennense Babin \&

Figure 3. A, B, E-H - Praenucula abrupta sp. nov. (Barrande, 1881). • A, B - left valve, JK 14939, holotype; A - lateral view, $\times 2.9$; B - dorso-lateral view, $\times$ 4.6. $\bullet \mathrm{E}, \mathrm{F}$ - left valve, JK 14937, paratype; E - lateral view, $\times 4.3$; F - dorso-lateral view, $\times 6.5$. • G, H - right valve, JK 14944, paratype; G - lateral view, $\times 4.2 ; \mathrm{H}$ - dorso-lateral view, $\times 7.4 . \bullet \mathrm{C}, \mathrm{D}, \mathrm{I}, \mathrm{J}-$ Praenucula dispar (Barrande, 1881). $\bullet \mathrm{C}, \mathrm{D}-\mathrm{left}$ valve, JK 14943; C - lateral view, $\times 2.9$; $\mathrm{D}$ - dorso-lateral view, $\times 5.3$. $\bullet \mathrm{I}, \mathrm{J}-$ right valve, JK 14931; I - lateral view, $\times 7.6 ; \mathrm{J}-$ dorso-lateral view, $\times 10 . \bullet \mathrm{K}-$ Myoplusia sp., right valve, lateral view, JK 14968, × 3.5. • L, M - Sluha kosoviensis (Barrande, 1881), right valve, JK 14966; L - dorso-lateral view, $\times 3.5 ;$ M - lateral view, $\times 4$. - N-Q - Praeleda compar (Barrande, 1881), articulated specimen, JK 14935; N - dorsal view, $\times 5.7$; O - detail of the posterior part of hinge with pedal muscle scars, $\times 8$; P - left lateral view, $\times 4.2$; Q - right lateral view, $\times 4.3$. $・$ A-J, L-Q - decalcified siltstone nodules, Kosov Formation, Hirnantian, uppermost Ordovician, Praha-Běchovice (Marek 1963b). • K - coarse sandstones, Kosov Formation, Hirnantian, uppermost Ordovician, shallow syncline north of Praha-Běchovice. 

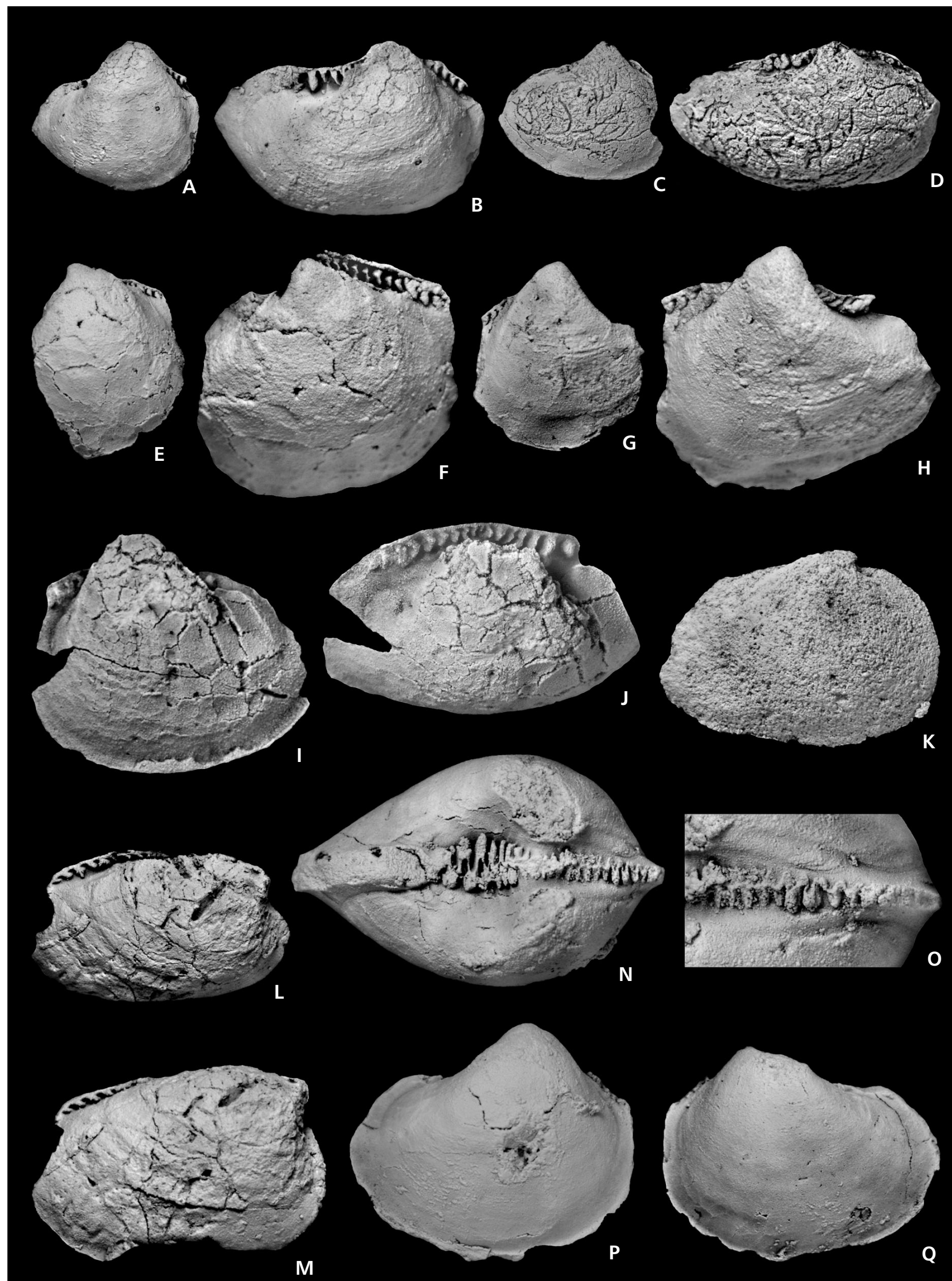
Beaulieu, 2003 from the Middle Ordovician of the Armorican Massif has more elongated and also concave anterior part of the dorsal margin. Praenucula dispersa Tunnicliff, 1982 from the Bardahessiagh Formation, Upper Ordovician of Pomeroy, Ireland, has more numerous teeth in the posterior (12 and more in number) and anterior (13 and more in number) parts of the hinge. Praenucula infirma Tunnicliff, 1982 from the Killey Bridge Formation, Upper Ordovician of Pomeroy, Ireland, differs from Praenucula dispar by larger teeth in the anterior part of the shell and also by elongated anterior part of the shell. Praenucula praetermissa Tunnicliff, 1982 from the Killey Bridge Formation, Upper Ordovician of Pomeroy has umbones more in central position and more numerous teeth than Praenucula dispar. $P$. infirma and $P$. praetermissa also differ from Praenucula dispar in concave anterior part of the shell.

\section{Praenucula abrupta sp. nov.}

Figure 3A, B, E-H

Holotype. - Internal mould of the left valve, JK 14939, figured on Fig. 3A, B.

Paratypes. - Internal moulds of the left valve JK 14937 and the right valve JK 14944, figured on Fig. 3E-H.

Derivation of name. - From Latin abruptus, precipitous, steep.

Type locality. - Bohemia, Prague Basin, temporary outcrop in the research institutions area, north of PrahaBěchovice (Marek 1963b).

Type horizon. - Upper Ordovician, late Hirnantian, Kosov Formation.

Material. - Two left valves and three right valves.

Diagnosis. - Praenucula with triangular shell, prominent prosogyrate umbones, and with concave anterior part of the dorsal margin.

Description. - Shell small, equivalve, inequilateral, triangular. Anterior part of the shell is larger. Anterior part of the dorsal margin is concave, posterior part straight. Anterior and posterior margins rounded, ventral margin convex. Prominent umbones are in the posterior half of the shell length or in central position, prosogyrate. Hinge taxodont. Posteriorly of umbo the teeth are small (7-10 in number), anteriorly slightly larger (7-8 in number). In posterior part of the shell the hinge line is straight. In anterior part of the shell the hinge line is concave. Inner surface with narrow growth bands and furrows developed. Anterior adductor muscle scar rounded. Other muscle scars unknown. Outer surface sculpture and the shell thickness are unknown.

$\begin{array}{llrrr}\begin{array}{l}\text { Dimensions. - } \\ \text { specimen }\end{array} & \text { V } & \mathrm{L} & \mathrm{H} & \mathrm{W} / 2 \\ \text { JK } 14950 & \mathrm{R} & 5.6 & 4.9 & 2.2 \\ \text { JK } 14937 & \mathrm{~L} & - & 8.4 & 2.9 \\ \text { JK } 14944 & \mathrm{R} & 8.2 & 8.7 & 2.8 \\ \text { JK } 14939 & \mathrm{~L} & 11.1 & 10.2 & 4.0\end{array}$

Discussions. - Praenucula sharpei Babin \& Gutiérrez Marco, 1991 is more longitudinally elongated than Praenucula abrupta sp. nov. Praenucula mayennense Babin $\&$ Beaulieu, 2003 has more elongated anterior part and less prominent umbo, but very similar concave anterior part of the dorsal margin. Praenucula dispar has more numerous teeth in the posterior (12 and more in number) and in the anterior (13 and more in number) parts of the hinge and more elongated anterior part of the shell. Praenucula infirma Tunnicliff, 1982 differs from Praenucula abrupta sp. nov. by larger teeth in the anterior part of the shell and also by elongated anterior part of the shell. Praenucula praetermissa Tunnicliff, 1982 has very similar shape with Praenucula abrupta sp. nov., but has more teeth in the anterior part of the hinge (more than 9 in number). $P$. infirma and $P$. praetermissa show concave anterior part of the dorsal margin as in Praenucula abrupta sp. nov.

\section{Genus Praeleda Pfab, 1934}

Type species. - Praleda compar (Barrande, 1881), Bohemia, Prague Basin, Loděnice, Ordovician, late Sandbian, Zahořany Formation.

Figure 4. A-E - Praeleda compar (Barrande, 1881). • A-C - articulated specimen, JK 14930; A - left lateral view, $\times 3.8$; B - dorsal view, $\times 7.1$; $\mathrm{C}$-right lateral view, $\times 3.4$. $\bullet \mathrm{D}, \mathrm{E}-$ left valve, JK 14936; D - dorso-lateral view, $\times 4.8$; E - detail of the outer surface sculpture, $\times 5.7$. $\bullet$ F, G, I, J - Myoplusia obtusa (Barrande, 1881), articulated specimen, JK 14942; F - right lateral view, $\times 3.8$; G - anterior view, $\times 3.5$; I - detail of pedal muscle scars, $\times 8.3 ; \bullet \mathrm{J}$ - dorsal view, $\times 5$. $\bullet \mathrm{H}, \mathrm{K}, \mathrm{L}-$ Metapaleoneilo dromon sp. nov., H - left valve, lateral view, JK 14958, paratype, $\times 3.4 ; \mathrm{K}-$ right valve, lateral view, JK 14956, paratype, $\times 5.8$; L - right valve, lateral view, JK 14959, holotype, × 6.2. • A-G, I, J - decalcified siltstone nodules, Kosov Formation, Hirnantian, uppermost Ordovician, Praha-Běchovice (Marek 1963b). • H, K, L - coarse sandstones, Kosov Formation, Hirnantian, uppermost Ordovician, Praha-Běchovice (Marek 1963b). 


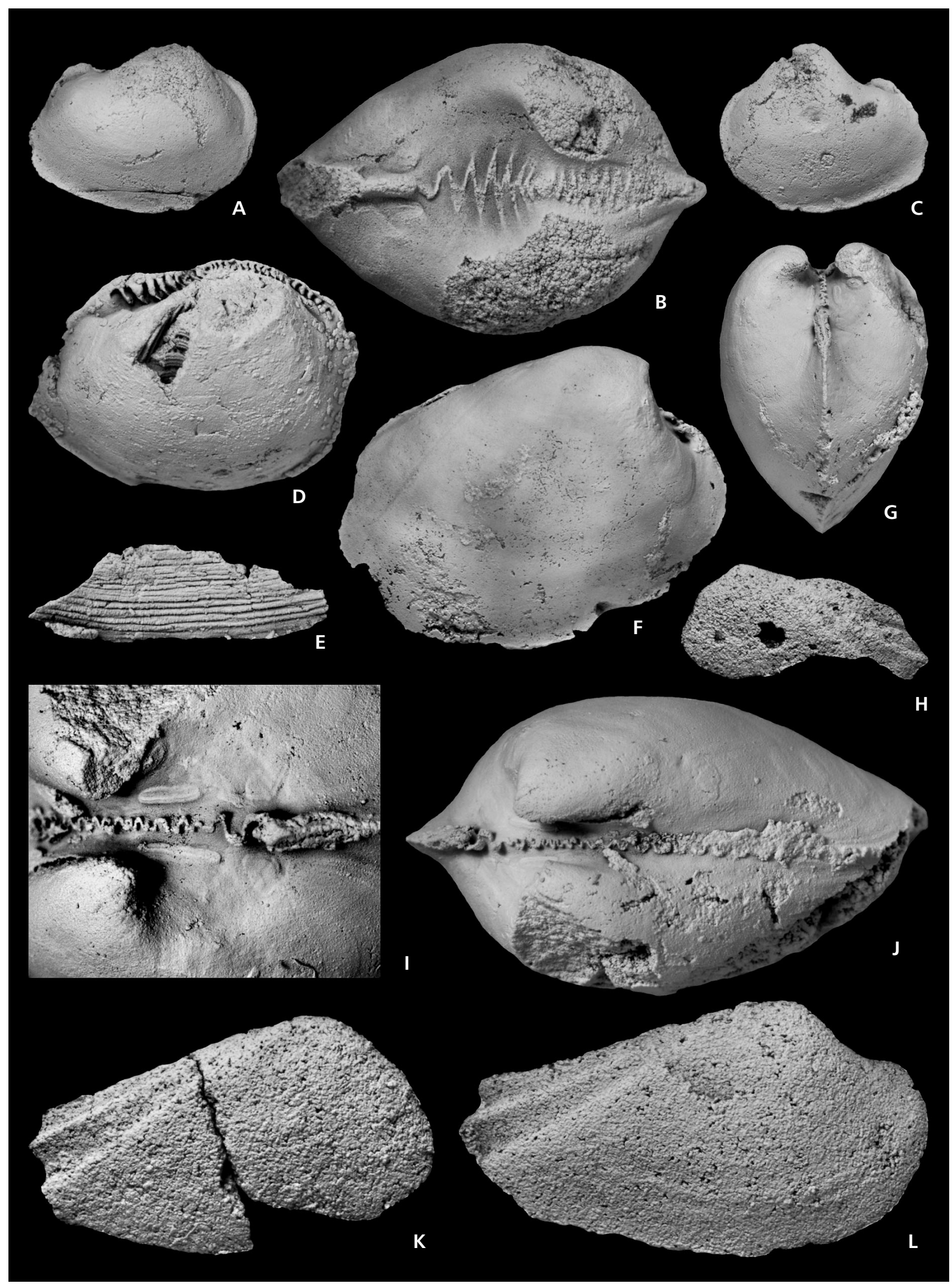


Remarks. - In Praeleda the posterior part of the hinge plate is much longer than the anterior and bears variable number of equal-sized teeth. The few of the anterior teeth increase in size anteriorly and there is commonly (but not always) angular discordance between anterior and posterior dentitions. The hinge axis lies along the line of more numerous posterior teeth, and anterior commonly larger teeth lie ventrally of it. Because of these features Cope $(1997,1999)$ grouped into the family Cardiolariidae Cope, 1997 (Cardiolarioidea Cope, 2000) also Praeleda having the posterior dentitions in which the hinge axis lies parallel with the line of posterior teeth. The anterior line of teeth, which may be enlarged, lie below the hinge axis but the teeth row between the umbones is continuous contrary to Ordovician Cardiolaria Munier-Chalmas, 1876.

Carter (2001, p. 220) is of the opinion that the most important for diagnosis of Cardiolariidae is the presence of anterior palaeotaxodont or pseudotaxodont teeth abruptly enlarged relative to the posterior palaeotaxodont teeth. According to Cope (2005) the cardiolarioids are a small group of taxodont bivalves with hinge designed for wider valve opening facilitating more effective disposal of pseudofaeces and directly linked to the development of the filibranch gill. According to Cope (1999) they represent the earliest autolamellibranch bivalves. We are of the opinion that Praeleda should be classified in Praenuculidae where it was placed by Babin \& Beaulieu (2003), and summarised by Pojeta \& Stott (2007).

\section{Praeleda compar (Barrande, 1881)}

Figures 3N-Q, 4A-E

1881 Nucula compar Barr.; Barrande, pl. 271, figs III/1-14. 1881 Nucula amica Barr.; Barrande, pl. 271, figs I/1-16.

1934 Praeleda compar (Barr.). - Pfab, pl. III, figs 1-3.

1968 Praeleda compar (Barrande). - McAlester, p. 46, pl. 7, figs $1-9$, pl. 8, figs $1,2$.

Lectotype. - Internal mould of the shell with conjoined valves, figured by Barrande (1881) on pl. 271, as figs III/9-11, NM L 27 176. Designed by McAlester (1968).

Paralectotypes. - Internal moulds of the shells with conjoined valves, figured by Barrande (1881) on pl. 271, as figs III/ 1-4, 5-8, 12-14, 15-16, NM L27144, L27148, L27146, L27147.

Type locality. - Bohemia, Prague Basin, Loděnice.

Type horizon. - Upper Ordovician, late Sandbian, Zahořany Formation.

Material. - Three shells with conjoined valves, one left valve from Praha-Běchovice.

Diagnosis. - Praeleda with broadly subelliptic to ovate shells, with 7 to 8 teeth in the anterior part of the hinge and with 15-20 teeth in the posterior part of the hinge.

Description. - Small, equivalve, inequilateral, and broadly subelliptic to ovate shell. Anterior and posterior margins evenly rounded, ventral margin convex. Anterior part is larger part of the shell. Umbones are in the posterior half of the shell length. Dorsal margin in the anterior part of the shell is slightly concave, in the posterior part of the shell it is convex. Outer surface sculpture consists of numerous, regularly spaced growth bands and furrows. Inner surface sculpture is smooth. The hinge taxodont, the posterior part with small numerous teeth (15-20 in number), and the anterior part of the shell with abruptly much larger teeth (7-8 in number). Teeth row between the umbones is not interrupted. Anterior adductor muscle scar elliptic and larger than rounded posterior adductor muscle scar. One pair of rounded pedal muscle scars (protractors) is developed posteriorly from the anterior adductor muscle scars, one pair of transverse elliptic pedal muscle scars (retractors) is developed anteriorly from the posterior adductor muscle scar, and two pairs of the narrowly elliptical accessory muscle scars are developed in the umbonal region.

$\begin{array}{lcrrr}\begin{array}{l}\text { Dimensions. }- \\ \text { specimen }\end{array} & \text { V } & \text { L } & \text { H } & \text { W/2 } \\ \text { JK 14934 } & \text { A } & 10.1 & 8.5 & 2.5 \\ \text { JK 14930 } & \text { A } & 11.5 & 8.9 & 2.8 \\ \text { NM L27144 } & \text { A } & 11.5 & 9.1 & 3.2 \\ \text { NM L27146 } & \text { A } & 11.9 & 9.3 & 3.6 \\ \text { JK 14936 } & \text { L } & 12.0 & - & 4.2 \\ \text { JK 14935 } & \text { A } & 12.1 & 9.7 & 3.5 \\ \text { NM L27145 } & \text { A } & 12.5 & 9.3 & 3.75 \\ \text { NM L27143 } & \text { A } & 13.2 & 11.3 & 3.7\end{array}$

Figure 5. A-C, E-L - Sluha kosoviensis (Barrande, 1881). A - right valve, JK 14961, lateral view, × 2.2. • B - right valve, JK 14979, lateral view, $\times 2.3$. $\bullet$ C - left valve, JK 14972, lateral view, $\times 2.4$. $\bullet$ E - left valve, JK 14985, detail of outer surface sculpture, $\times 2.4$. $\bullet$ F, G - left valve, JK $14984 ;$ F - lateral view, $\times 2.5 ; \mathrm{G}-$ dorso-lateral view, $\times$ 4.4. $\bullet \mathrm{H}-$ left valve, JK 14962, lateral view, $\times 1.9$. $\bullet$ I, J - left valve, JK $14976 ; \mathrm{I}-$ lateral view, $\times 2.1$; $\mathrm{J}$ - dorso-lateral view, $\times 4.0 . \bullet \mathrm{K}, \mathrm{L}$ - articulated specimen, JK $14978 ; \mathrm{K}$ - dorsal view, $\times 3$; L - right lateral view, $\times 2.0$. $\bullet$ D - Myoplusia sp., right valve, lateral view, JK 14955, × 12. All specimens come from the decalcified siltstone nodules, Kosov Formation, Hirnantian, uppermost Ordovician, Praha-Běchovice (Marek 1963b). 

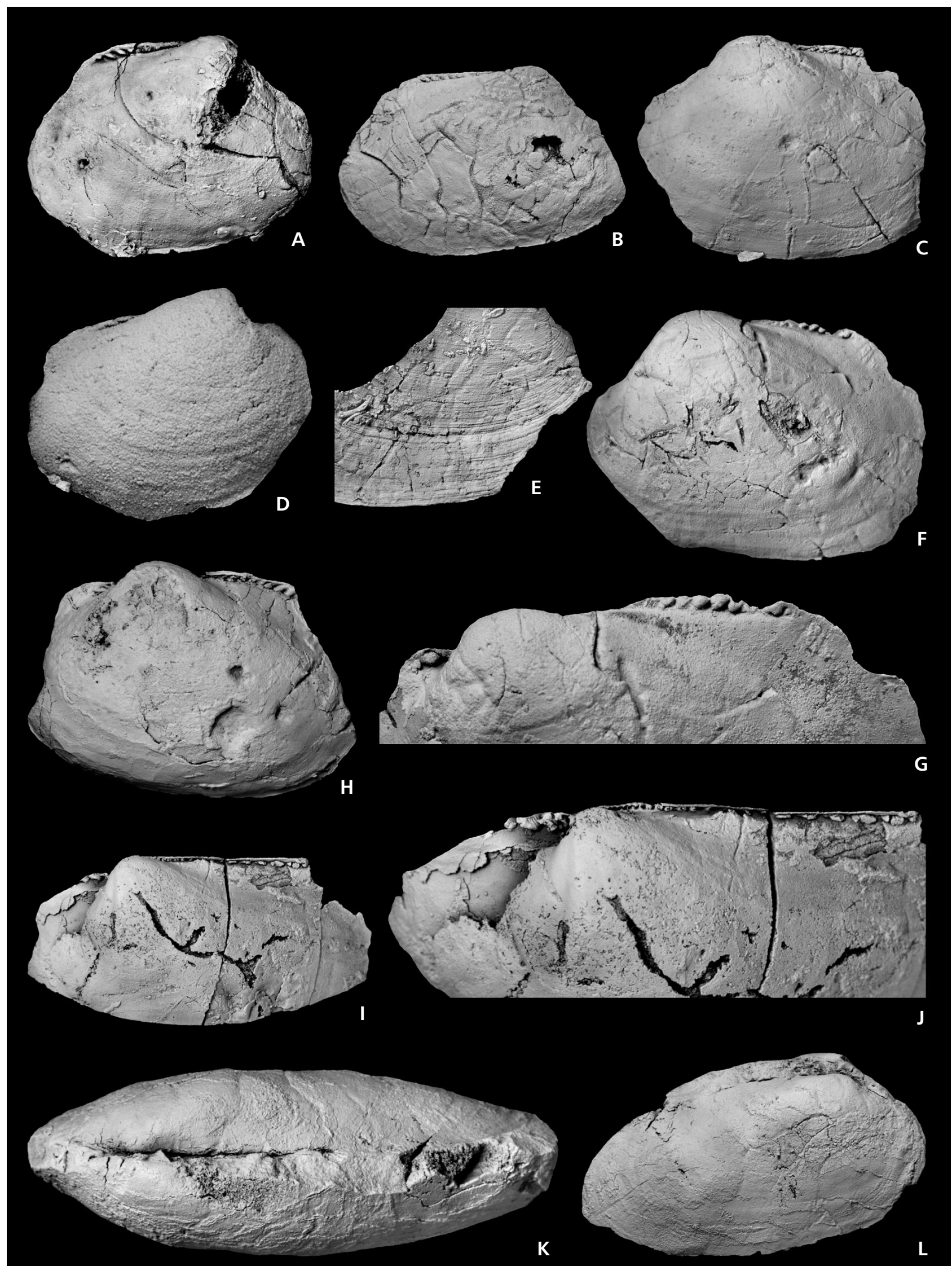
Discussion. - Pfab (1934) determined four species of the genus Praeleda: Praeleda compar (Barrande, 1881), Praeleda amica (Barrande, 1881), Praeleda pulchra Pfab, 1934 and Praeleda contrastans (Barrande, 1881). Babin \& Melou (1972) recognized the species Praeleda contrastans as Myoplusia contrastans. We suppose that Praeleda compar and Praeleda amica are synonymous. Praeleda pulchra is more elongated than other two species of Praeleda recognized by Pfab (1934) and also the anterior dorsal margin is more concave. Our specimens are also closely related to Praeleda costae (Sharpe, 1853) from the Middle Ordovician, Finistère, France (Bradshaw 1971, 1978), but they differ by less longitudinally elongated shells and by generally more numerous teeth. Praeleda multidentata Cope, 1999 from the Middle Ordovician of Mid-Wales and the Welsh Borderland has more numerous and smaller teeth in the anterior part of the shell than Praeleda compar. Praeleda subtilis Cope, 1999 from the Middle Ordovician of Mid-Wales and the Welsh Borderland differs from Praeleda compar by slight posterior alation, and by smaller teeth.

Family Nuculitidae Bradshaw, 1999

\section{Genus Nuculites Conrad, 1841}

Type species. - Nuculites oblongatus Conrad, 1841, USA, New York, Chenango County, near Smyrna, Middle Devonian.

\section{Nuculites aff. planulatus Conrad, 1841}

Figure 6A-I

Material. - Two right valves, two left valves, and two shells with conjoined valves.

Description. - Shell equivalved, inequilateral, ovate or longitudinally elongated. Umbones are prominent, in the anterior part of shell, beaks prosogyrate. The septum is relatively short and extends from anterior part of the hinge line towards the anterior margin of the shell. Posterior hinge line straight, the anterior hinge line curved ventrally. Orthomorph teeth are larger in the posterior part of the hinge. Inner surface sculpture is smooth. The anterior adductor muscle scar is mostly distinct, occupying much of the portion of the shell anteriorly to the septum. A transversely narrowly elliptic pedal muscle scar is developed anteriorly of the umbo close to the dorsal margin. Posterior adductor muscle scar, outer surface sculpture and thickness of the shell are unknown.

$\begin{array}{llrrr}\begin{array}{l}\text { Dimensions. - } \\ \text { specimen }\end{array} & \text { V } & \text { L } & \text { H } & \text { W/2 } \\ \text { JK } 14957 & \text { R } & 7.2 & 4.8 & 2.3 \\ \text { JK } 14941 & \text { L } & 9.0 & 7.1 & 3.0 \\ \text { JK } 14983 & \text { R } & 10.0 & 6.1 & 1.9 \\ \text { JK } 14945 & \text { L } & 13.2 & 6.5 & 2.1 \\ \text { JK } 14974 & \text { A } & - & 8.9 & 4.2 \\ \text { JK } 14932 & \text { A } & - & 10.6 & 4.1\end{array}$

Discussion. - Variation in the shell form is characteristic for Nuculites. Bretsky \& Bretsky (1977) demonstrated high variability in Nuculites planulatus Conrad, 1841 from the Nicolet River Formation type section, Upper Ordovician of Quebec, Canada. They revised four previously described species: Nuculites postvolutus (Foerste, 1914) with well developed radial sinus extending to the posteroventral edge of the shell, Nuculites praevolutus (Foerste, 1914) with radial sinus extending to the antero-ventral edge of the shell, Nuculites planulatus Conrad, 1841 s.s. with smooth shell and no sinus, and Nuculites brevis (Foerste, 1914), which is relatively short and high. They refer all these species, on the base of systematic detailed study of morphological variability, to Nuculites planulatus, which differs from the Bohemian specimens by the development of the radial sinus, except the specimens of Nuculites planulatus s.s.

The high variability in Nuculites cylindricus (Portlock, 1843) from the Killey Bridge Formation, Upper Ordovician of Pomeroy, Ireland, which is very similar to Nuculites planulatus, was described by Tunnicliff (1982). In Nuculites cylindricus is also developed the posterior shallow radial sinus close to the ventral margin, which is not developed in our specimens. Both species Nuculites planulatus and Nuculites cylindricus from the Upper Ordovician are very closely related and because of their similar variability and general shell form they may be synonymous. In that case, Nuculites cylindricus (Portlock, 1843) is the junior synonym of Nuculites planulatus Conrad, 1841. Barrande (1881) figured Nuculites fissa (pl. 267, figs VI/1-3) from the Upper Ordovician, Prague Basin,

Figure 6. A-I - Nuculites aff. planulatus Conrad, 1841. • A, D, E - left valve, JK 14941; A - dorsal view, detail of pedal muscle scar, $\times 7.5$; D - lateral view, $\times 6$; E - dorso-lateral view, $\times 7$. • B - left valve, lateral view, JK 14945, × 3.9. • C, G - articulated specimen, JK 14974; C - dorsal view, $\times 2.2 ; \mathrm{G}-$ dorsal view, $\times 4.9 . \bullet \mathrm{F}, \mathrm{H}, \mathrm{I}-$ articulated specimen, JK 14932; F - right lateral view, $\times 2.7$; H - dorsal view, $\times 4.2 ; \mathrm{I}-$ dorso-lateral view, detail of the septum, $\times 5.7$. $\bullet \mathrm{J}, \mathrm{K}-$ Myoplusia contrastans (Barrande, 1881), left valve, JK 14980; J - dorso-lateral view, $\times 9.4$; K - dorsal view, $\times$ 7.9. All specimens come from the decalcified siltstone nodules, Kosov Formation, Hirnantian, uppermost Ordovician, Praha-Běchovice (Marek 1963b). 

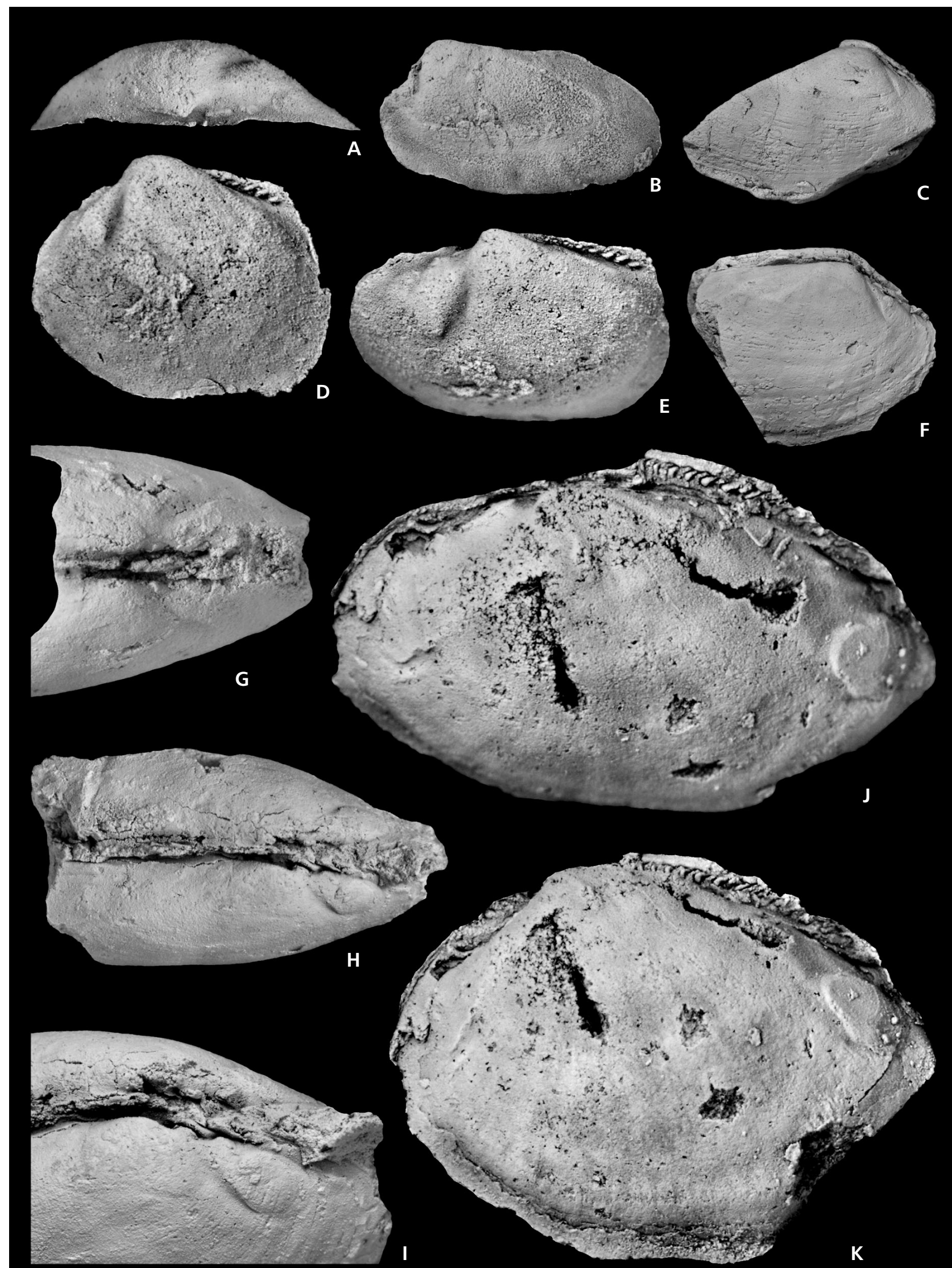
Praha-Krč, Bohemia, which differs by the short septum oriented slightly posteriorly.

Superfamily Nuculanoidea Adams \& Adams, 1858

Family Malletiidae Adams \& Adams, 1858

\section{Genus Sluha Barrande, 1881}

Type species. - Sluha expansus Barrande, 1881, Bohemia, Prague Basin, Lejškov Hill, Upper Ordovician, middle and upper Katian, Králův Dvůr Formation.

\section{Sluha kosoviensis (Barrande, 1881)}

Figures 3L-M, 5A-C, E-L

1881 Arca? kosoviensis Barr.; Barrande, pl. 265, figs III/1-12. 1881 Arca? disputabilis Barr.; Barrande, pl. 265, figs I/13-15.

1881 Arca? innotata Barr.; Barrande, pl. 265, figs II/1-20.

1891 Praearca kosoviensis (Barr.). - Neumayr, p. 755.

1934 Praearca kosoviensis (Barr.). - Pfab, p. 220, pl. 3, fig. 21.

1934 Ctenodonta praecox (Barr.). - Pfab, p. 228, pl. 2, fig. 14.

1934 Ctenodonta disputabilis (Barr.). - Pfab, p. 228, pl. 2, fig. 15.

1934 Ctenodonta (Palaeoneilo) flectens (Barr.). - Pfab, p. 230, pl. 2, fig. 18 .

1934 Ctenodonta (Palaeoneilo) magna (Barr.). - Pfab, p. 231, pl. 2, fig. 19.

1968 Praearca kosoviensis (Barrande). - McAlester, pp. 44,45 , pl. 30, figs $1-8$.

1969 Sluha kosoviensis (Barrande). - McAlester, p. N235.

Lectotype. - Internal mould of a right valve figured by Barrande (1881) on pl. 265, as figs III/ 9-10, NM L27070. Designed by Pfab (1934).

Paralectotypes. - Internal mould of the shell with articulated and opened valves figured by Barrande (1881), on pl. 265 as fig. III/1, NM L27072; internal mould of the shell with articulated and opened valves figured by Barrande (1881), on pl. 265, as fig. III/ 2, NM L27071; internal mould of the left valve figured by Barrande (1881) on pl. 265 as figs III/3-5, NM L27073; internal mould of the right valve figured by Barrande (1881), pl. 265, as figs III/6-8, NM L27069; internal mould of a left valve figured by Barrande (1881), pl. 265, as figs III/11-12, NM L27068.

Type locality. - Bohemia, Prague Basin, Kosov Hill near Beroun.

Type horizon. - Upper Ordovician, late Katian, uppermost Králův Dvůr Formation.
Material. - Eight right valves, five left valves, and one shell with conjoined valves from Praha-Běchovice.

Diagnosis. - Upper Ordovician longitudinally elongated Sluha with the anterior smaller and the posterior larger part; taxodont dentition developed anteriorly and posteriorly of umbo.

Description. - Shell medium size, equivalved, inequilateral, broadly ovate, and longitudinally elongated $(\mathrm{H} / \mathrm{L}=$ 0.5-0.8). Anterior part of the shell is smaller. Anterior and posterior margins evenly rounded, ventral margin long and convex, postero-dorsal angle rounded, and dorsal margin slightly convex. Umbones prominent, in anterior half of the shell, beaks are prosogyrate. Umbonal ridge well defined, becoming obsolete before reaching post-inferior extremity. Outer surface sculpture consists of fine growth wrinkles. Inner surface is smooth. Ligament is probably external. Hinge line in anterior part of the shell slightly curved ventrally, in posterior part straight or slightly convex. Taxodont teeth are small, in the posterior part of the hinge line slightly larger, and with obliquely orthomorph shape (according to Babin 1966, p. 39). Muscle scars unknown.

$\begin{array}{llrrr}\begin{array}{l}\text { Dimensions. }- \\ \text { specimen }\end{array} & \text { V } & \mathrm{L} & \mathrm{H} & \mathrm{W} / 2 \\ \text { JK 14966 } & \mathrm{R} & 16.2 & 10.1 & - \\ \text { JK } 14971 & \mathrm{R} & - & 14.4 & 4.2 \\ \text { JK } 14960 & \mathrm{R} & 21.1 & - & 3.5 \\ \text { JK } 14973 & \mathrm{R} & 21.4 & 15.2 & 4.2 \\ \text { JK 14979 } & \mathrm{R} & 22.4 & 17.0 & 5.6 \\ \text { JK 14961 } & \mathrm{R} & 24.1 & 19.0 & 6.5 \\ \text { NM L27072 } & \mathrm{A} & 25.9 & 12.0 & 5.6 \\ \text { NM L27071 } & \mathrm{A} & 26.2 & 15.2 & 5.6 \\ \text { JK 14972 } & \mathrm{L} & - & 17.2 & 6.2 \\ \text { JK 14984 } & \mathrm{L} & 27.3 & 21.1 & 7.1 \\ \text { NM L27070 } & \mathrm{R} & 29.0 & 17.2 & 3.1 \\ \text { NM L27069 } & \mathrm{R} & 31.1 & 21.8 & 3.5 \\ \text { JK 14978 } & \mathrm{A} & 31.3 & 15.7 & 5.1 \\ \text { NM L27068 } & \mathrm{L} & 31.8 & 21.2 & 2.5 \\ \text { JK 14964 } & \mathrm{L} & - & 23.7 & 6.5 \\ \text { JK 14962 } & \mathrm{L} & 34.1 & 24.5 & 6.3\end{array}$

Discussions. - Pfab (1934) included Arca? kosoviensis Barrande, 1881 and Arca? innotata Barrande, 1881 in the genus Praearca established by Neumayr (1891) for Arca? kosoviensis Barrande, 1881 and Arca? disputabilis Barrande, 1881. McAlester (1969) concluded that Praearca represents a junior synonym of Sluha Barrande, 1881. Sluha kosoviensis (Barrande, 1881) is probably a direct descendant of Sluha expansus Barrande, 1881, and differs from it by the longitudinally more elongated shells and by a fine taxodont dentition along the posterior and anterior hinge margins. 


\section{Genus Myoplusia Neumayr, 1884}

Type species. - Myoplusia bilunata (Barrande, 1881), Bohemia, Prague Basin, Štěrboholy, Upper Ordovician, late Sandbian, Zahořany Formation.

\section{Myoplusia contrastans (Barrande, 1881)}

Figure 6J, K

1881 Nucula contrastans Barr.; Barrande, pl. 271, figs II/1-16.

1934 Praeleda contrastans (Barr.). - Pfab, p. 233, pl. III, figs 4, 7-9.

1972 Myoplusia contrastans (Barrande). - Babin \& Melou, pp. 83-85, pl. 7, figs 8-10, pl. 8, figs $1-3$.

Lectotype. - Internal mould of the shell with conjoined valves figured by Barrande (1881), pl. 271, as figs II/1-4, NM L22680. Designated by Pfab (1934).

Paralectotypes. - Internal mould of the shell with conjoined valves figured by Barrande (1881), pl. 271, as figs II/ 5-8, NM L22681; other specimens figured by Barrande (1881) on pl. 271 as figs 9-16, could not be located.

Type locality. - Bohemia, Prague Basin, Praha-Libeň.

Type horizon. - Upper Ordovician, late Sandbian, Zahořany Formation.

Material. - One left valve from Praha-Běchovice.

Diagnosis. - Myoplusia with the hinge teeth of similar size in anterior and posterior parts, and with the straight anterior part of the dorsal margin.

Description. - Shell small, equivalve, inequilateral, ovate, and longitudinally elongated. Umbones are in the anterior half of the shell length, beaks prosogyrate. Anterior part of the shell is smaller than the posterior part of the shell. Hinge taxodont, teeth in the anterior part of the hinge are ill-preserved, posterior part of the hinge consists of convex and orthomorph teeth (according to Babin 1966, p. 39). Convex teeth are close to the umbo, orthomorph teeth are far from the umbo, close to the posterior end of the dorsal margin. Inner surface sculpture is smooth. Anterior adductor muscle scar is less distinct, elliptical, posterior adductor muscle scar prominent, elliptical. One pair of narrowly transversely elliptical pedal muscle scars is developed posteriorly from the anterior adductor muscle scar. Three accessory narrowly elliptical muscle scars preserved in the umbonal region. Integripallial line well preserved, composed of the radially elongated pallial muscle scars. Outer surface sculpture and shell thickness are unknown.
Dimensions. -

$\begin{array}{llrrr}\text { specimen } & \text { V } & \text { L } & \text { H } & \text { W/2 } \\ \text { JK 14980 } & \text { L } & 11.3 & 10.1 & 4.1 \\ \text { NM L22680 } & \text { A } & 11.9 & 9.0 & 3.5\end{array}$

Discussion. - Pfab (1934) included erroneously Nucula contrastans Barrande, 1881 (pl. 271, figs II/1-16) and $\mathrm{Nu}$ cula applanans Barrande, 1881 (pl. 272, figs III/13-16) in Praeleda Pfab, 1934 which has the larger anterior part of the shell (Bradshaw 1971), and prosogyrate umbo in the posterior position. Myoplusia has the larger posterior part of the shells, umbo in anterior position and is prosogyrate. Myoplusia contrastans differs from Myoplusia bilunata (Barrande, 1881) in straight anterior part of the dorsal margin, the less prominent umbo and by the anterior and posterior teeth of same size. Myoplusia obtusa (Barrande, 1881) differs from Myoplusia contrastans in more obese shell and by shorter anterior part of the hinge.

\section{Myoplusia obtusa (Barrande, 1881)}

Figure 4F, G, I, J

1881 Nucula obtusa Barr.; Barrande, pl. 272, figs I/1-17. 1934 Pseudocyrtodonta obtusa (Barr.). - Pfab, pl. III, fig. 12.

Lectotype. - Internal mould of the shell with conjoined valves, figured by Barrande (1881) on pl. 272, as figs I/12-14, NM L22683. Designated by Pfab (1934).

Paralectotypes. - Internal mould of the shell with conjoined valves, figured by Barrande (1881) on pl. 272, as figs I/1-4, NM L27150; internal mould of the shell with conjoined valves, figured by Barrande (1881) on pl. 272, as figs I/5-8, NM L22684; internal mould of the shell with conjoined valves, figured by Barrande (1881) on pl. 272, as figs I/9-11, NM L22685; internal mould of the shell with conjoined valves, figured by Barrande (1881) on pl. 272, as figs I/15-17, NM L22686.

Type locality. - Bohemia, Prague Basin, Praha-Štěrboholy.

Type horizon. - Upper Ordovician, late Sandbian, Zahořany Formation.

Material. - One shell with conjoined valves from PrahaBěchovice.

Diagnosis. - Myoplusia with obese shell, very short anterior part of hinge and with the teeth increasing in size anteriorly and posteriorly from umbo.

Description. - Shell is small, equivalve, inequilateral, inflated, posteriorly elongated; anterior part of the shell is 
shorter. Umbones are prominent, in anterior position, and beeks prosogyrate. Posterior dorsal margin of the shell is slightly convex. Anterior, ventral and posterior margins are evenly rounded. Hinge is taxodont, teeth row continues below the umbo without interruption. Teeth below the umbo are smaller and their size slightly increases anteriorly and posteriorly. Internal surface is smooth. Anterior adductor muscle scar is relatively large, broadly elliptical. Posterior adductor muscle scar is larger than anterior muscle scar, broadly elliptical. Two pairs of pedal muscle scars are developed posteriorly of the anterior adductor muscle scar. First pair of elliptical pedal protractor muscle scars is close to the anterior adductor and close to hinge line. Second pair of transversely narrowly elliptical anterior pedal retractor muscle scars is developed posteriorly from the protractors, which are close and subparallel to the hinge line. Other deeply impressed elliptical accessory muscle scar is developed on the left valve close to the umbo and ventrally from the second pair of the pedal muscle scars. We suppose that it was probably the third pair of the pedal muscle scars or a median muscle scar.

$\begin{array}{llrrr}\begin{array}{l}\text { Dimensions. - } \\ \text { specimen }\end{array} & \text { V } & \text { L } & \text { H } & \text { W/2 } \\ \text { NM L22686 } & \text { R } & 6.5 & 5.6 & 2.6 \\ \text { NM L27150 } & \text { A } & 6.6 & 5.5 & 2.1 \\ \text { NM L22684 } & \text { A } & 8.5 & 6.3 & 2.3 \\ \text { NM L22683 } & \text { A } & 8.6 & 5.8 & 2.0 \\ \text { JK 14942 } & \text { A } & 19.2 & 14.2 & 4.6\end{array}$

Discussion. - Pfab (1934) classified Barrande's two (1881) species "Leda" ala and "Nucula" obtusa as the genus Pseudocyrtodonta Pfab, 1934 with the type species Pseudocyrtodonta ala (Barrande, 1881). In the type material of this species the hinge is mostly not preserved, and this was probably the main reason why Pfab distinguished the new genus. In other two specimens of "Leda" ala Barrande, 1881 (pl. 273, figs II/4-5, 6-8) the hinge shows taxodont teeth in the smaller anterior part of the shell and in the larger posterior part of the shell. McAllester (1969) classified Pseudocyrtodonta as synonym of Myoplusia. The other species classified by Pfab (1934) as Pseudocyrtodonta was "Nucula" obtusa Barrande, 1881. The lectotype of this species exhibits a different shape of shell, not so much longitudinally elongated and with less narrowed posterior part. The taxodont hinge is preserved only in the anterior part of the shell. Lectotype shows preserved three elongated umbonal accessory muscle scars in the umbonal region. The general shape is very similar to the genus Myoplusia.

“Leda” incola Barrande, 1881 (pl. 270, III/1-4), classified by Pfab (1934) as Pseudocyrtodonta ala (Barrande, 1881) has prominent prosogyrate beaks, very elongated shell, narrowed posteriorly. The taxodont hinge is well preserved in the anterior part of the shell. Posterior and ante- rior rounded adductor muscle scars and elongate accessory muscle scars in the umbonal region are well developed. Most of these features are characteristic for Myoplusia, only the elongated shape with narrowed posterior of the shell differs. This shape is very similar to the Recent genus Propeleda Iredale, 1924.

Myoplusia bilunata (Barrande, 1881) differs from Myoplusia obtusa by less obese, more longitudinally elongated shell, and by larger anterior part of the shell.

\section{Myoplusia sp.}

Figures 3K, 5D

Material. - Two right valves, one left valve.

Discussions. - Poorly preserved specimens with only general shape of the shell preserved. Umbones are prominent, almost in central position, beaks prosogyrate. The anterior part of the shell is smaller than the posterior part of the shell. Anterior, ventral, and posterior margins are evenly rounded. Part of taxodont hinge (Fig. 5D) is preserved in posterior part of the dorsal margin. Inner surface with regularly spaced narrow growth bands and furrows (Fig. 5D).

Occurrence. - One (Fig. 3K) specimen was found in the sandstone beds with the Modiolopsis pragensis Community exposed by temporary pipeline outcrop along the western margin of the research institution's area north of Praha-Běchovice. The point is marked on the geological map as the geologically significant locality No. 6 in Straka (1987, p. 66). The other specimen (Fig. 5D) was found in the temporary outcrop in the territory of the research institution's area north of Praha-Běchovice (Marek 1963b).

\section{Genus Metapalaeoneilo Lamcke, 1934}

Type species. - Palaeoneilo (Metapalaeoneilo) baltica Lamcke, 1934, Germany, Schilksee near Kiel, Beyrichienkalk, upper Přídolí, late Silurian.

\section{Metapalaeoneilo dromon sp. nov.}

\section{Figure 4H, K, L}

Holotype. - Internal mould of the left valve, JK 14959, figured on Fig. 4L.

Paratypes. - Internal moulds of the left valve and the right valve, JK 14958 and JK 14956 figured on Fig. 4H, K.

Derivation of name. - From Greek dromon - light, fast vessel. 
Type locality. - Bohemia, Prague Basin, temporary outcrop in the research institutions area, north of Praha-Běchovice (Marek 1963b).

Type horizon. - The Upper Ordovician, late Hirnantian, upper Kosov Formation, coarse sandstone with the Modiolopsis pragensis Community.

Material. - Two right valves and one left valve.

Diagnosis. - Posteriorly elongated Metapalaeoneilo with two radial umbonal ridges and two wide radial sinuses or folds developed closely to dorsal margin and extending radially from the umbo to the posterior extremity.

Description. - Shell small, equivalve, inequilateral, posteriorly elongated. The umbones are relatively large, prosogyrate, anteriorly of central part of the shell. Dorsal margin is straight. Ventral margin long, convex. Anterior margin evenly rounded. Between the umbo and the posterior extremity two radial umbonal ridges and two deep sinuses are developed. Inner surface with the growth bands and furrows developed. Muscle scars and hinge unknown.

\section{Dimensions. -} specimen

\section{JK 14956}

JK 14959

JK 14958

\section{V}

$\mathrm{R}$

$\mathrm{R}$

$\mathrm{L}$
L

13.1

14.2

15.0

\section{$\mathrm{H}$}

8.1

8.3

6.6
$\mathrm{W} / 2$

1.6

1.4 1.6
Discussion. - Metapalaeoneilo dromon sp. nov. differs from the type species Metapalaeoneilo baltica by the longitudinally elongated shell and by the two umbonal ridges and two deep sinuses developed closely to dorsal margin and extending radially to the posterior extremity.

Occurrence. - Type locality only.

Subclass Autolamellibranchiata Grobben, 1894

Superorder Pteriomorphia Beurlen, 1944

Superfamily Ambonychioidea Miller, 1877

Family Ambonychiidae Miller, 1877

\section{Genus Mytilarca Hall \& Whitfield, 1869}

Type species. - Inoceramus chemungensis Conrad, 1842, U.S.A., New York, Upper Devonian, Chemung Stage.

Remarks. - The genus Mytilarca is known from the Upper Ordovician, Silurian and Devonian. In general, the specific classification is very difficult when only general mytiliform shape, outer and inner surface sculpture is known
(Růžička \& Prantl 1961, Pojeta 1966, Kř́ž 2008). Since it is out of the scope of this paper to revise all the representatives of Mytilarca described in the past we compare our specimens found in upper Hirnantian only with the Upper Ordovician species described in the past from Sweden (Isberg 1934).

\section{Mytilarca mareki sp. nov.} Figure 7A-T

1982 Cyrtodonta sp. - Štorch, p. 231, pl. 2, fig. 9.

Holotype. - Internal mould of the right valve with posterior laterals preserved, JK 15020, figured on Fig. 7N-P.

Paratypes. - JK 14986-JK 15015, JK 15018-JK 15019, JK 15021-JK 15046, JK 15054-JK 15062 measured for dimensions, included into assemblage analysis and figured on Fig. 7A-M, Q-T.

Derivation of name. - In honour of Ladislav Marek, palaeontologist from the Czech Academy of Sciences, expert in the Lower Paleozoic Hyolitha.

Type locality. - Bohemia, Praha-Běchovice, temporary outcrop in the research institution's area, north of the village (Marek 1963b).

Type horizon. - Upper Ordovician, latest Hirnantian, uppermost Kosov Formation, decalcified nodules in the bioturbated claystones.

Material. - 21 left, 41 right valves, and eight shells with conjoined valves.

Diagnosis. - Mytilarca with postero-ventrally elongated broadly ovate shells.

Description. - Shells are small $(\mathrm{L}=11.5-29.8 ; \mathrm{H}=$ 11.8->24.6), broadly ovate, equivalved, inequilateral, and obese ( $\mathrm{W}=6.2-14.6)$, lacking the anterior lobe. Umbones are prominent, in extreme terminal position, beaks prosogyrate. Outer surface sculpture consists of growth wrinkles and of irregular flat growth bands and furrows. Byssal sinus weak, no byssal gape developed. Ligament external, low ligament area with numerous duplivincular grooves and ridges. Hinge in the left valve composed of two elongated cardinal teeth just behind umbo, posterior one longer. In the posterior part of the shell, close to the hinge line one to three narrow lateral teeth are developed. A relatively large, subcircular posterior adductor muscle scar is developed in postero-dorsal part of the shell. Shell very thin $(>0.05 \mathrm{~mm})$. 
Dimensions. -

$\begin{array}{lrrrr}\text { specimen } & \mathrm{V} & \mathrm{L} & \mathrm{H} & \mathrm{W} / 2 \\ \text { JK 15 018 } & \mathrm{R} & 4.1 & 3.6 & 1.3 \\ \text { JK 15 021 } & \mathrm{L}(\mathrm{A}) & 5.5 & 5.4 & 1.5 \\ \text { JK 14 992 } & \mathrm{R} & 8.7 & 9.2 & 2.6 \\ \text { JK 15 004 } & \mathrm{R} & 9.8 & 9.2 & 2.4 \\ \text { JK 14 993 } & \mathrm{R} & 11.5 & 11.8 & 3.1 \\ \text { JK 15 020 } & \mathrm{R} & >12.5 & 13.4 & 4.1 \\ \text { JK 15 042 } & \mathrm{L}(\mathrm{A}) & 16.7 & 16.8 & 4.8 \\ \text { JK 15 036 } & \mathrm{L} & - & 19.8 & 7.1 \\ \text { JK 14 987 } & \mathrm{R} & 23.5 & 21.1 & 7.3 \\ \text { JK 15 012 } & \mathrm{R} & 29.8 & >24.6 & 7.1\end{array}$

Discussion. - Mytilarca mareki sp. nov. differs from all the species described by Isberg (1934) by broadly ovate, posteroventrally elongated shells. Mytilarca semicircularis Isberg, 1934 from the late Ordovician of Dalarna, Sweden differs by very broadly ovate to broadly elliptic shells and hinge composed of three small cardinals of which the middle one is longest. Some species of toothless Cleionychia Ulrich, 1892 from the Middle and late Ordovician of North America, Korea, Ireland, Norway, Sweden and Kazakhstan, Russia (Pojeta 1966) have similar general shape.

Mode of life. - Semi-infaunal, byssate.

Occurrence. - Type locality and Praha- ̌̌epy, temporary outcrop, uppermost Kosov Formation, late Hirnantian, Upper Ordovician (Štorch 1982).

Superfamily Modiolopsoidea Fischer, 1887

Family Modiolopsidae Fischer, 1887

\section{Genus Modiolopsis Hall, 1847}

Type species. - Pterinea modiolaris Conrad, 1838, U.S.A., New York, Pulaski Formation, Ordovician.

\section{Modiolopsis pragensis sp. nov.}

Figures 8H-U, 9

Holotype. - Internal mould of the left valve, JK 15097, figured on Fig. 8M.
Paratypes. - JK 15047-15053, 15065-15096, 15098-15114, measured for dimensions, included into assemblage analysis and figured on Fig. 8H-L, N-U.

Derivation of name. - After the capital of the Czech Republic, Praha (Lat. Praga).

Type locality. - Bohemia, Praha-Běchovice, temporary outcrop in the research institution's area, north of village (Marek 1963b).

Type horizon. - Upper Ordovician, latest Hirnantian, uppermost Kosov Formation, decalcified nodules from the bioturbated claystones.

Material. - One shell with conjoined valves, 45 left and 54 right valves.

Diagnosis. - The elongated late Ordovician Modiolopsis with the lobate anterior part and with the posterior part a little larger than the anterior part of the shell, the outer surface sculpture formed by irregular growth wrinkles; hinge edentulous.

Description. - Shell medium in size (maximum L = 38.0 ), elongated, slightly diagonally modioliform, equivalve, inequilateral $(\mathrm{L} / \mathrm{H}=1.33-2.10)$. Shells are inflated with no distinct umbonal ridge; maximum width at about one third of the shell length from anterior $(\mathrm{H} / \mathrm{W}=$ 1.05-2.13, high variability is probably caused by vertical diagenetic deformations). Anterior part lobate, evenly rounded, posterior part of the shell is a little larger than anterior part. Maximum height is reached approximately in the last quarter of the shell length from anterior. Umbones not prominent, beaks small, close together, slightly above the hinge line, in one quarter of the shell length from anterior, and prosogyrate. Dorsal margin is long, more than one half of the shell length, straight. Ventral margin is long, slightly convex. Posterior margin evenly rounded. Outer surface sculpture composed of irregularly spaced growth wrinkles. Ligament opisthodetic. Hinge plate edentulous, muscle scars and pallial line not developed.

Figure 7. Mytilarca mareki sp. nov. $\bullet$ A - right lateral view, JK 15018 , paratype, $\times 7 . \bullet B, C$-articulated specimen, JK 15021 , paratype; B - right lateral view, $\times 4.8$; C - dorso-lateral view, $\times 7.2$. $\bullet$ D - antero-lateral left view, JK 15042, paratype, $\times 1.7 . \bullet$ E - right lateral view, detail of hinge, JK 15005 , paratype, $\times 10.5$. $\bullet \mathrm{F}, \mathrm{Q}$ - right valve, JK 15061, paratype; F - dorso-lateral view, detail of the lateral teeth, $\times 4.6$; Q - lateral view, $\times 3.3$. $\bullet \mathrm{G}-$ dorso-lateral view of the left valve, detail of the lateral teeth, JK 14989, paratype, $\times 4.3$. $\bullet \mathrm{H}$ - right lateral view, detail of hinge, JK 15000, paratype, $\times 4.4$. $\bullet$ I, R - right valve, JK 14987 , paratype; I - lateral view, detail of the lateral teeth, $\times 3.4 ; \mathrm{R}$ - lateral view, $\times 2.1 . \bullet \mathrm{J}, \mathrm{T}$ - right valve, JK 14993, paratype; J - dorso-lateral view, detail of the lateral teeth, $\times 6.3$; T - lateral view, $\times 4.1$. $\bullet \mathrm{K}$ - left valve, outer surface sculpture, JK 15029, paratype, $\times 3.6 . \bullet \mathrm{L}, \mathrm{S}-$ right valve, JK 14992 , paratype; $\mathrm{L}-$ dorso-lateral view of the left valve, detail of the lateral teeth, $\times 7.4 ; \mathrm{S}$ - lateral view, $\mathrm{x} 6 . \bullet \mathrm{M}$ - dorso-lateral right view, detail of duplivincular ligament area, JK 14997 , paratype, $\times 8.0$. - N-P - right valve, JK 15020, holotype; $\mathrm{N}$ - dorsal view, $\times 4$; O - dorso-lateral view, detail of the lateral teeth, $\times 5.2 ; \mathrm{P}-$ lateral view, $\times 4.8$. $\bullet$ All specimens come from the decalcified siltstone nodules, Kosov Formation, Hirnantian, uppermost Ordovician, Praha-Běchovice (Marek 1963b). 


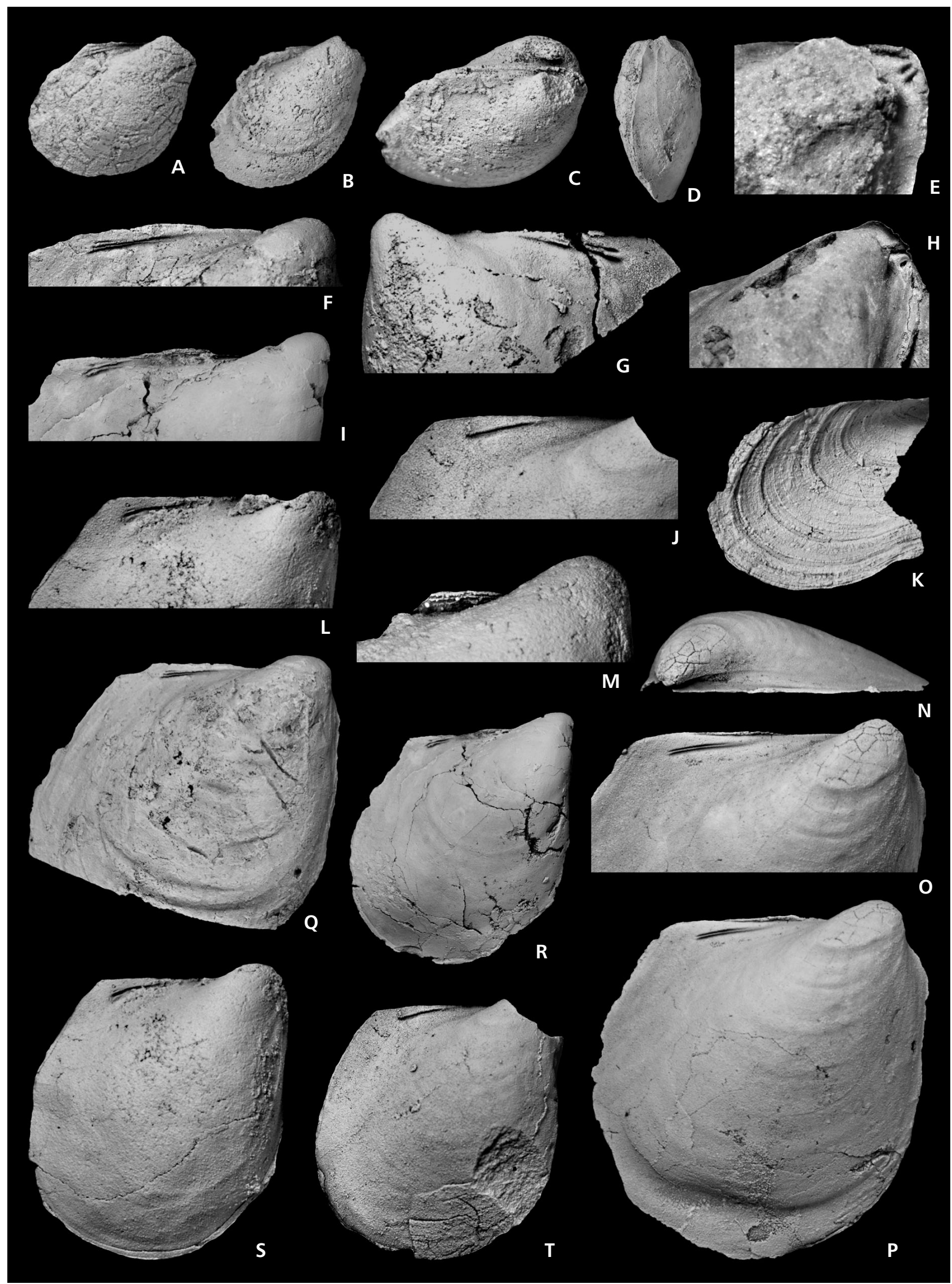




\begin{tabular}{|c|c|c|c|c|c|}
\hline \multicolumn{6}{|c|}{ Dimensions. - Longer forms $(\mathrm{L} / \mathrm{H}=1.62-2.10)$} \\
\hline specimen & V & $\mathrm{L}$ & $\mathrm{H}$ & $\mathrm{W} / 2$ & $\mathrm{~L} / \mathrm{H}$ \\
\hline JK 15073 & $\mathrm{~L}$ & 8.9 & 4.8 & 1.9 & 1.85 \\
\hline JK 15111 & $\mathrm{R}$ & 15.1 & 8.6 & 2.9 & 1.76 \\
\hline JK 15112 & $\mathrm{R}$ & 16.8 & 9.6 & 3.6 & 1.75 \\
\hline JK 15047 & $\mathrm{~L}$ & 20.1 & 10.2 & 4.5 & 1.97 \\
\hline NM L40574 & $\mathrm{R}$ & 22.5 & 11.2 & - & 2.00 \\
\hline JK 15075 & $\mathrm{~L}$ & 23.1 & 13.6 & 4.5 & 1.70 \\
\hline JK 15049 & $\mathrm{~L}$ & 23.3 & 14.1 & 4.1 & 1.65 \\
\hline JK 15092 & $\mathrm{R}$ & 23.5 & 13.3 & 5.6 & 1.77 \\
\hline JK 15050 & $\mathrm{R}$ & 24.0 & 12.0 & 4.6 & 2.00 \\
\hline JK 15077 & $\mathrm{R}$ & 24.2 & 13.6 & 5.4 & 1.78 \\
\hline JK 15079 & $\mathrm{R}$ & 24.3 & 11.6 & 5.5 & 2.09 \\
\hline JK 15085 & $\mathrm{R}$ & 26.3 & 15.7 & 5.4 & 1.68 \\
\hline JK 15114 & $\mathrm{~L}$ & 26.4 & 13.5 & 6.0 & 1.96 \\
\hline JK 15088 & $\mathrm{R}$ & 27.0 & 14.9 & 7.1 & 1.81 \\
\hline JK 15097 & $\mathrm{~L}$ & 27.7 & 13.9 & 6.0 & 1.99 \\
\hline JK 15086 & $\mathrm{R}$ & 28.2 & 16.6 & 5.4 & 1.70 \\
\hline JK 15051 & $\mathrm{R}$ & 29.3 & 18.1 & 6.3 & 1.62 \\
\hline JK 15091 & $\mathrm{R}$ & 29.5 & 16.3 & 7.1 & 1.81 \\
\hline NM L40576 & $\mathrm{R}$ & 31.5 & 17.4 & 5.6 & 1.81 \\
\hline NM L40575 & $\mathrm{L}$ & 34.0 & 17.8 & - & 1.91 \\
\hline JK 15099 & $\mathrm{~L}(\mathrm{~A})$ & 34.4 & 16.4 & 6.9 & 2.10 \\
\hline JK 15090 & $\mathrm{R}$ & 34.7 & 18.5 & 7.0 & 1.88 \\
\hline NM L40577 & $\mathrm{L}$ & 38.0 & 20.1 & 6.9 & 1.89 \\
\hline
\end{tabular}

Shorter forms $(\mathrm{L} / \mathrm{H}=1.33-1.67)$

$\begin{array}{llrrrr}\text { specimen } & \mathrm{V} & \mathrm{L} & \mathrm{H} & \mathrm{W} / 2 & \mathrm{~L} / \mathrm{H} \\ \text { JK 15069 } & \mathrm{L} & 10.6 & 7.5 & 2.9 & 1.41 \\ \text { JK 15102 } & \mathrm{R} & 15.0 & 11.0 & 4.0 & 1.36 \\ \text { JK 15084 } & \mathrm{R} & 15.0 & 11.3 & 4.6 & 1.33 \\ \text { JK 15093 } & \mathrm{L} & 19.1 & 12.7 & 4.9 & 1.50 \\ \text { JK 15082 } & \mathrm{L} & 19.5 & 12.7 & 4.5 & 1.54 \\ \text { JK 15094a } & \mathrm{L} & 22.0 & 13.2 & 5.8 & 1.67 \\ \text { JK 15103 } & \mathrm{L} & >22.0 & 14.4 & 4.5 & 1.53 \\ \text { JK 15067 } & \mathrm{L} & 22.1 & 13.5 & 4.9 & 1.64 \\ \text { JK 15094b } & \mathrm{R} & 23.1 & 16.1 & 7.0 & 1.43 \\ \text { JK 15087 } & \mathrm{L} & 23.4 & 16.3 & 6.0 & 1.44 \\ \text { NM L40573 } & \mathrm{L} & 25.8 & 17.1 & 4.5 & 1.51 \\ \text { JK 15098a } & \mathrm{R} & 25.9 & 16.4 & 6.0 & 1.58 \\ \text { JK 15104 } & \mathrm{R} & 26.0 & 18.0 & 7.0 & 1.44 \\ \text { JK 15089 } & \mathrm{R} & 26.1 & 17.3 & 6.0 & 1.51 \\ \text { JK 15096 } & \mathrm{L} & 26.9 & 16.6 & 5.5 & 1.62 \\ \text { JK 15098b } & \mathrm{R} & 27.6 & 18.7 & 6.1 & 1.48 \\ \text { JK 15106 } & \mathrm{L} & 28.1 & 17.0 & 5.9 & 1.65 \\ \text { JK 15095 } & \mathrm{L} & 28.3 & 17.2 & 5.9 & 1.65 \\ \text { JK 15052 } & \mathrm{L} & 29.1 & 20.8 & 8.9 & 1.40 \\ \text { JK 15108 } & \mathrm{R} & 31.6 & 20.9 & 4.9 & 1.51\end{array}$

Discussion. - In the past, more than 163 Ordovician species were classified under Modiolopsis Hall, 1847 (Pojeta 1971). In general, the specific classification is very difficult when only general modioliform shape and outer surface sculpture formed by growth wrinkles, are known.
Since it is out of the scope of this paper to revise all the representatives of the Ordovician Modiolopsis described in the past, we compare Modiolopsis pragensis with the Ordovician type species Modiolopsis modiolaris (Conrad, 1838) which differs generally by more elongated and larger shells, elongated prominent anterior lobe, slightly concave ventral margin and deeply impressed anterior adductor muscle scar and pallial line. On the specimen figured by Pojeta 1971 (pl. 15, figs 1-3) the posterior myophoric buttress described by Liljedahl (1994) in Modiolopsis alvae Liljedahl, 1994 from the late Wenlock of Gotland is clearly visible.

Most closely is related Modiolopsis draboviensis Barrande, 1881 from the Upper Ordovician, Sandbian, Letná Formation sandstones, Děd Hill near Beroun, the Prague Basin. It is similar to Modiolopsis pragensis in early juvenile stages with almost parallel dorsal and ventral margins but late in ontogeny the posterior part becomes distinctly larger and higher than anterior part of the shell (see lectotype of Modiolopsis draboviensis, Fig. 8V). Adult specimens of Modiolopsis veterana Barrande, 1881 from the late Sandbian, Zahořany Formation, Zahořany near Beroun, the Prague Basin, differ from Modiolopsis pragensis in postero-ventrally extended shells, relatively short dorsal margin, in prominent umbonal ridge, slightly concave ventral margin, regularly spaced growth bands and furrows, and in deeply impressed anterior adductor muscle scar. "Modiolopsis" primula Barrande, 1881, from the Upper Ordovician, Sandbian, Letná Formation, sandstones, Děd Hill near Beroun, the Prague Basin, differs from Modiolopsis pragensis in very high and short shells $(\mathrm{L}=17.6, \mathrm{H}=16.8, \mathrm{~L} / \mathrm{H}=1.05)$ and in prominent impression of the anterior adductor muscle scar. "Modiolopsis" lenticularis Barrande, 1881 and "Modiolopsis" faba Barrande, 1881 from the Upper Ordovician, late Katian, upper Králův Dvůr Formation, Prague Basin, Bohemia have very high shells $(\mathrm{L} / \mathrm{H}=1.16$ and 1.11) and most probably do not represent the genus Modiolopsis. "Modiolopsis" minuta Barrande, 1881 from the Králův Dvůr Formation (late Katian), differs from the genus Modiolopsis in its well-developed posterior wing, separated from the rest of shell by a radial sulcus. Modiolopsis tumescens Barrande, 1881 described from the same stratigraphic level differs in a less developed anterior lobe. Modiolopsis cuyana Sánchez, 1990 from the Hirnantian of Argentina differs from Modiolopsis pragensis in distinctly shorter shells with relatively very high posterior part. Modiolopsis elegantulus Sharpe, 1853 from the Middle Ordovician of Portugal and the Massif Armoricain, France, and from the Upper Ordovician of Finistère (Babin \& Beaulieu 2003) differs from Modiolopsis pragensis in concave ventral margin.

Occurrence. - Modiolopsis pragensis occurs in the Prague area, Prague Basin, Bohemia and is known from the Home- 
rian, the upper Kosov Formation coarse- grained sandstones and quartzites of Tachlovice, Praha-Nová Ves, PrahaHodkovičky, and Praha-Běchovice.

Mode of life. - Most probably infaunal. The valves of Modiolopsis pragensis are mostly found disarticulated and washed out on the bedding planes of the sandstone. Shells with conjoined valves also occur but they are rare. On some bedding planes very abundant, disarticulated and relatively very small juveniles are found. Two overlapping forms (shorter $-\mathrm{L} / \mathrm{H}=1.33-1.67$ and longer $-\mathrm{L} / \mathrm{H}=1.62-2.10$ ) co-occur in the coarse grained sandstones to quartzites of the high Hirnantian, Kosov Formation at the Praha-Běchovice, Praha-Hodkovičky and Tachlovice localities.

Superorder Anomalodesmata Dall, 1889

Superfamily Pholadomyoidea Gray, 1847

\section{?Genus Sphenolium Miller, 1889}

Type species. - Orthodesma cuneiforme Miller, 1881, Upper Ordovician, upper part of the Hudson River Group, near Versailles, Indiana, U.S.A.

Remarks. - Sphenolium Miller, 1889 was first related by Newell (1969, p. N818) and by Pojeta 1971 (?Sphenolium striatum Ulrich, 1894) to anomalodesmatans. Later Pojeta (1978, pl. 7, figs 7-9, pl. 8, fig. 6) figured Sphenolium sp. nov., under investigation, with the anterior tooth above the anterior adductor muscle scar, the posterior tooth above the posterior adductor muscle scar, and with the ligament area crossed by horizontal grooves as the typical Ordovician cyrtodontid. In agreement with Pojeta (1971) we consider ?Sphenolium parallelum Ulrich, 1894 and ?Sphenolium striatum Ulrich, 1894 to be closely related to anomalodesmatans. The Bohemian specimens determined here as ?Sphenolium cf. parallelum Ulrich, 1894 are closely related to ?Sphenolium parallelum by general shape of the shell. ?Sphenolium striatum from the Upper Ordovician, Goodhue County, Minnesota differs in development of radial striae on the inner surface of dorsal slopes and on the umbonal ridge. More precise comparison and generic determination is impossible due to lack of material.

\section{?Sphenolium cf. parallelum Ulrich, 1894}

Figure $8 \mathrm{~A}-\mathrm{G}$

Material. - One incomplete left valve and one open articulated shell.

Description. - Small lanceolate shell $(\mathrm{L}=10.4, \mathrm{H}=5.1$, $\mathrm{W} / 2=2.4$ ) is strongly inequilateral, longitudinally elon- gated, inflated $(\mathrm{H} / \mathrm{W}=1.06)$. Umbo is prominent, in almost terminal anterior position, closely incurved, prosogyrate. Valve is subdivided by sinuous, prominent rounded diagonal umbonal ridge between umbo and postero-ventral extremity. Dorsal margin is straight, more than half of the shell length. Posterior end of dorsal margin is blunt. Dorsal and ventral margins are subparallel. Posterior margin is obliquely rounded. Ventral margin is long, convex. Short anterior margin is evenly rounded. In front of the umbo small lunule is developed. Inner surface sculpture is formed of irregularly spaced narrow growth bands and furrows. Other features not preserved.

Discussion. - ?Sphenolium parallelum Ulrich, 1894 from the Upper Ordovician, Trenton Formation, Mineral Point, Wisconsin (Bassler, 1915, p. 1170 listed this species as being from the Platteville of Blackriver age and from Richmond age rocks) is not congeneric with Sphenolium and differs from the type species Sphenolium cuneiforme (Miller, 1881), Sphenolium richmondense Miller, 1889 from the Upper Ordovician of Indiana, and from Sphenolium faberi Miller, 1889 from the Upper Ordovician of Ohio especially by the longitudinally elongated shells with almost parallel dorsal and ventral margins.

Occurrence. - Uppermost Ordovician, late Hirnantian, upper Kosov Formation, siltstone nodules, Bohemia, Prague Basin, Praha-Běchovice, temporary outcrop in the research institution's area, north of village (Marek 1963b).

Mode of life. - Burrowing, infaunal.

\section{Community analysis}

Two communities were already distinguished in the upper Hirnantian of the Prague Basin by Havlíček (1982). The community dominated by Modiolopsis aff. draboviensis Barrande, 1881 (= Modiolopsis pragensis sp. nov.) inhabited the shallow-water plains with a substrate of lightcoloured, coarse grained quartzose sandstones. In the moderately deepened eastern part of the Prague Basin in the uppermost Hirnantian at the top of the Kosov Formation Havlíček distinguished (1982) the Hirnantia sagittifera Community. It is formed by a rich suite of articulate brachiopods described in detail by Marek \& Havlíček (1967), inarticulate brachiopods, gastropods, bivalves, orthocone nautiloids, sedentary cystoids, crinoids, trilobites, ostracods, chlorophytes, and graptolites, which were not revised in 1982. For the classification and analysis of the Bivalvia dominated communities we followed the methodology used by Kř́rž (1999). 


\section{Modiolopsis Community Group}

Barrande (1881) described Modiolopsis draboviensis as the only common bivalve in the Upper Ordovician, Sandbian, Letná Formation sandstones, Děd Hill near Beroun, the Prague Basin. Here it occurs in the community together with dominant Dalmanitina socialis (Barrande, 1852) and Deanaspis goldfussi (Barrande, 1846). Barrande (1881) also figured Modiolopsis draboviensis (= Modiolopsis pragensis sp. nov.) from the late Hirnantian sandstones, the upper Kosov Formation, localities Tachlovice and Praha-Hodkovičky where it is dominant and forms the characteristic community. The species of the genus Modiolopsis are dominant in many communities since the Lower Ordovician (Babin 1966, Babin \& Hamman 2001). Walker \& Bambach (1974) described and analyzed as example the low diversity Modiolopsis Community with dominant Modiolopsis sp. from the unstable, high stress shallow environment of the lower Silurian Ross Brook Formation, Arisaig, Nova Scotia, Canada. From the less rigidly controlled facies of the lower Silurian Ross Brook Formation, Arisaig, Nova Scotia they described and analyzed the Pteronitella-Nuculites Community, where Modiolopsis sp. is also dominant but the community is more diversified and contains less dominant pterineid and grammysioid bivalves, nuculoids, gastropods, cephalopods and trilobites. The Modiolopsis Community Group is characteristic for the shallow, high energy, and sandy inner shelf environment.

\section{Modiolopsis pragensis Community}

Name. - Used here for the first time.

Community group assignment. - Modiolopsis Community Group.

Composition. - Almost absolutely dominant Modiolopsis pragensis occurs together with rare gastropods Bucanella bohemica (Perner, 1903), Bucanellidae gen. indet., bivalves Myoplusia sp., Metapalaeoneilo dromon sp. nov., ros- troconch Ribeiria sp., trilobites Brongniartella sp., phyllocarid Ceratiocaris sp., brachiopods Aegiromena sp., Plectothyrela sp., common Cornulites sp., and sponge spicules. Modiolopsis pragensis is represented mostly by the disarticulated adult stages but on some bedding planes the juvenile stages are abundant.

Age. - Upper Kosov Formation, late Homerian, uppermost Ordovician. In the shales immediately above the sandstone with Modiolopsis pragensis occurs Normalograptus persculptus (Elles \& Wood, 1907).

Type locality. - Bohemia, Praha-Běchovice, shallow syncline north of the village. The best material was found in the pipeline outcrop along the western margin of the research institution's area. The point is marked as the geologically significant locality No. 6 in Straka (1987, p. 66).

Geographic distribution. - The Modiolopsis pragensis Community is known only from the Prague Basin, Bohemia. It is analogous and homologous (Boucot \& Kř́ž 1999) with the similar Modiolopsis draboviensis Community from the sandstones and quartzites, Upper Ordovician, Sandbian, Letná Formation, Děd Hill near Beroun, the Prague Basin. Here it occurs on the locally tectonically uplifted bottom of the basin. The Modiolopsis cuyana Community described by Sanchez (1990) from the Don Braulio Formation, Hirnantian, Argentina is also analogous and homologous to the Modiolopsis pragensis Community.

Environment interpretation. - The bivalves occur in the light-coloured mostly coarse-grained sandstone splitting readily into thin laminae. They are mostly disarticulated but rarely found as shells with conjoined valves. Other fossils are quite rare and frequently fragmentary. According to Štorch (1990) the coarse, storm generated sandstones represent the maximum regression in the upper part of the Hirnantian. According to Brenchley \& Storch (1989) their sedimentation was result of an additional regressive event when the shelf was channelled, and coarse material trans-

Figure 8. A-G-?Sphenolium cf. parallelum Ulrich, 1894. • A-D - left valve, JK 15016; A - dorsal view, detail of lunule, $\times 8.0$; B - lateral view, $\times 3.2$; $\mathrm{C}$-dorso-lateral view, $\times 3.6$; D - dorsal view, $\times 6.2$. $\bullet$ E-G - open articulated shell, JK 14953; E - dorsal view, $\times 2.0$; F - right lateral view, $\times 2.9$; G - left lateral view, $\times 3.7$. $\bullet \mathrm{H}-\mathrm{U}-$ Modiolopsis pragensis sp. nov.; H - right valve, JK 15084, paratype, lateral view, $\times 2.3$; I - left valve, JK 15087 , paratype, lateral view, $\times 1.8 ; \mathrm{J}$ - left pathological valve, JK 15081, paratype, lateral view, $\times 1.8 ; \mathrm{K}$ - right valve, JK 15088, paratype, lateral view, $\times 1.8 ; \mathrm{L}-$ left valve, JK 15052, paratype, lateral view, $\times 1.7 ; \mathrm{M}-$ left valve, JK 15097, holotype, lateral view, $\times 2.1 ; \mathrm{N}-$ right valve, JK 15104 , paratype, lateral view, $\times 1.6$; $\mathrm{O}, \mathrm{P}$ - shell with conjoined valves, JK 15099, paratype; O - dorsal view, $\times 1.7$; P - left lateral view, $\times 1.7$; R - left valve, JK 15082, paratype, dorso-lateral view, detail of the dorsal margin, $\times 3.4 ; \mathrm{S}-$ right valve, JK 15051 , lateral view, $\times 1.8 ; \mathrm{T}-$ pathological left valve, JK 15101 , paratype, lateral view, $\times 1.5$; $\mathrm{U}-$ right valve, JK 15090, lateral view, $\times 2.4 . \cdot \mathrm{V}-$ Modiolopsis draboviensis Barrande, 1881, left valve, NM L 27042 , holotype, lateral view, $\times 2.9$. - A-G - decalcified siltstone nodules, Kosov Formation, Hirnantian, uppermost Ordovician, Praha-Běchovice (Marek, 1963b). • H-U - coarse sandstones, Kosov Formation, Hirnantian, uppermost Ordovician, shallow syncline north of Praha-Běchovice. • V - sandstones, Letná Formation, Sandbian, Upper Ordovician, Děd Hill near Beroun. 


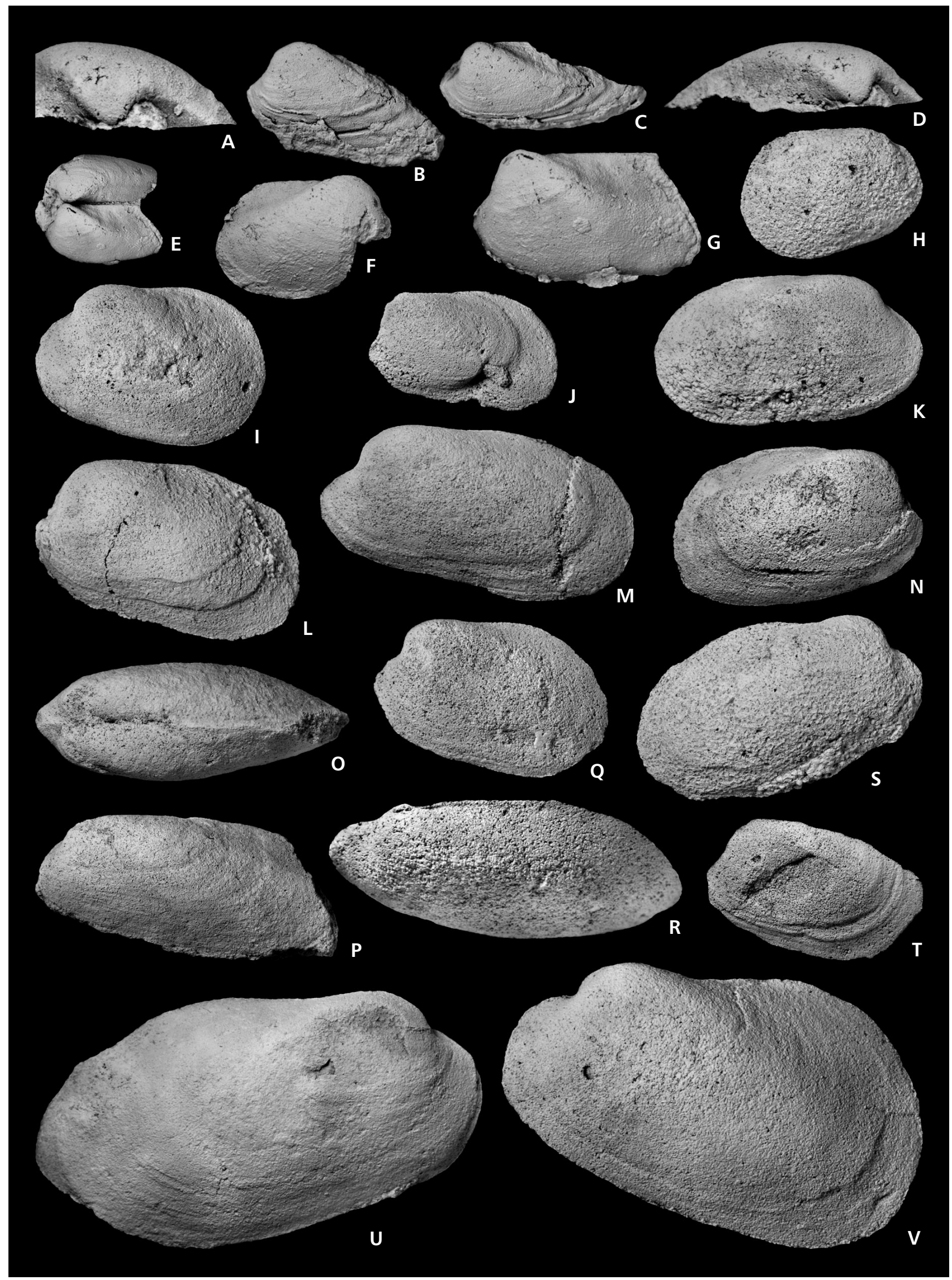


ported from the shore. The Modiolopsis pragensis Community is of low diversity (four species of bivalves) and has high population densities. It indicates restricted living conditions. Shells of the dominant semi-infaunal or infaunal Modiolopsis pragensis are mostly disarticulated, quite well preserved, almost none fragmented. Rarely also conjoined valves occur. Quite common adult pathological shells of Modiolopsis pragensis exhibit repairs of the shell border or fractures when mantle tissue was not permanently injured (Fig. 8J, T), and indicate high-energy environment during episodic events (storms etc.). On the bedding planes are concentrated mostly adult valves and on some bedding planes juveniles, most probably sorted by storm events. Other bivalves, gastropods, rostroconchs, brachiopods and trilobites occur rarely, disarticulated and fragmented. The Modiolopsis pragensis Community may be compared with the lower and middle Llandovery Orbiculoid-Linguloid and Pelecypod communities Benthic Assemblage 1-2 life zone of Boucot (1975), Havlíček \& Vaněk (1990).

\section{Hirnantia Community Group}

Temple (1965) described for the first time and analysed the Upper Ordovician Hirnantia fauna from the Holy Cross Mountains of Poland, Bardo syncline, Stawy Section (10 species of brachiopods), and from the Aber Hirnant, South-east of Bala, North Wales, Hirnant Quarry locality (11 species of brachiopods). Marek \& Havlíček (1967) described a diverse Hirnantia fauna (25 species of brachiopods) from the Prague Basin, PrahaBěchovice locality. Since that times the Hirnantia fauna has been described from many other parts of the World, e.g., Ireland, Sweden, central East Baltic, Carnic Alps, Morocco, Libya, North America, Kazakhstan, Norway, Yangtze and Western Yunnan-Tibet Regions, China (Havlíček 1989). Endemism is significant in the Hirnantian faunas (Lespérance 1974). According to Rong \& Harper (1988), and Sheehan (2001) the Hirnantia fauna extended from the circumpolar sphere into the temperate to tropical zones from the cold water environment of the Tindouf Basin (Morocco) to the South Sweden, Oslo-Asker District in Norway, and Ireland in proximity to the carbonate platforms (Havlíček 1989). The absence of the Hirnantian fauna over cratonic North America is explained as the result of the well-known disconformity at the base of the Silurian in the Mid-Continent (Lespérance 1974).

Lespérance \& Sheehan (1976) proposed the Hirnantia Community be used exclusively instead the Hirnantia fauna. We describe for the analogous and homologous communities the Hirnantia Community Group to substitute the term "Hirnantia fauna".

\section{Hirnantia sagittifera - Sluha kosoviensis Community}

Name. - The Hirnantia sagittifera Community was introduced by Havlíček (1982). The community is also characterized by the common nuculoid Sluha kosoviensis, by the diversified community of other nuculoids and by the dominant ambonychiid Mytilarca mareki. We propose to change the community name to the Hirnantia sagittiferaSluha kosoviensis Community to characterize better the brachiopod - bivalve dominance.

\section{Community group assignment. - Hirnantia Community} Group.

Composition. - Havlíček (1976) lists from the Bohemian localities in the eastern Prague Basin more than 25 species of benthic brachiopods (draboviids, aegiromenids, heterorthids and orthostrophiinids and inarticulates), described by Marek \& Havlíček (1967), and by Havlíček (1977, 1994). The articulate brachiopods are commonly preserved as shells with conjoined valves (Cryptothyrella sp., Plectothyrella platystrophoides Temple, 1965, Drabovia agnata Havlíček, 1967, a.o.). Inarticulate brachiopods are represented by the infaunal lingulid Rafanoglossa siliqua Havlíček, 1994, the epibenthic attached discinid Schizotretinia euxina Havlíček, 1994 and the trematid Tethyrete frigerum Havlíček, 1994, free-lying craniid Philhedra sp., and attached craniopsid Sanxiaella sp. (Mergl 1986). Rafanoglossa siliqua and Tethyrete frigerum occur mostly as the shells with conjoined valves. The gastropods Sinuitopsis hornyi Marek, 1963a, Grandostoma taconicum Marek, 1963a, Bucanella bohemica (Perner, 1903), Bucanellidae gen. indet., and Temnodiscus evolvens (Perner, 1903) were described by Marek (1963a). Important are bivalves Mytilarca mareki sp. nov., Modiolopsis cf. pragensis sp. nov., ?Sphenolium cf. parallelum Ulrich, 1894, Sluha kosoviensis (Barrande, 1881), Nuculites aff. planulatus Conrad, 1841, Praeleda compar (Barrande, 1881), Praenucula abrupta sp. nov., Myoplusia sp., Praenucula dispar (Barrande, 1881), Myoplusia obtusa (Barrande,1881), and Myoplusia contrastans (Barrande, 1881), trilobites Mucronaspis mucronata (Brongniart, 1822), Brongniartella platynota (Dalman, 1828), Eoleonaspis vondraceki (Šnajdr, 1987) and graptolite Normalograptus persculptus (Elles \& Wood, 1907). The conulariids, hexactinellids, trepostomate bryozoans, annelids, hyolitids, orthocone nautiloids, rare ostracods, phyllocarids, blastoids, cystoids, crinoids (preserved as individual columnals), dendroids and chlorophytes (receptaculitids) have not yet been systematically revised.

Age. - The Hirnantia sagittifera-Sluha kosoviensis Community occurs a few metres below the base of the Silurian in the Uppermost Kosov Formation, late Homerian, upper 


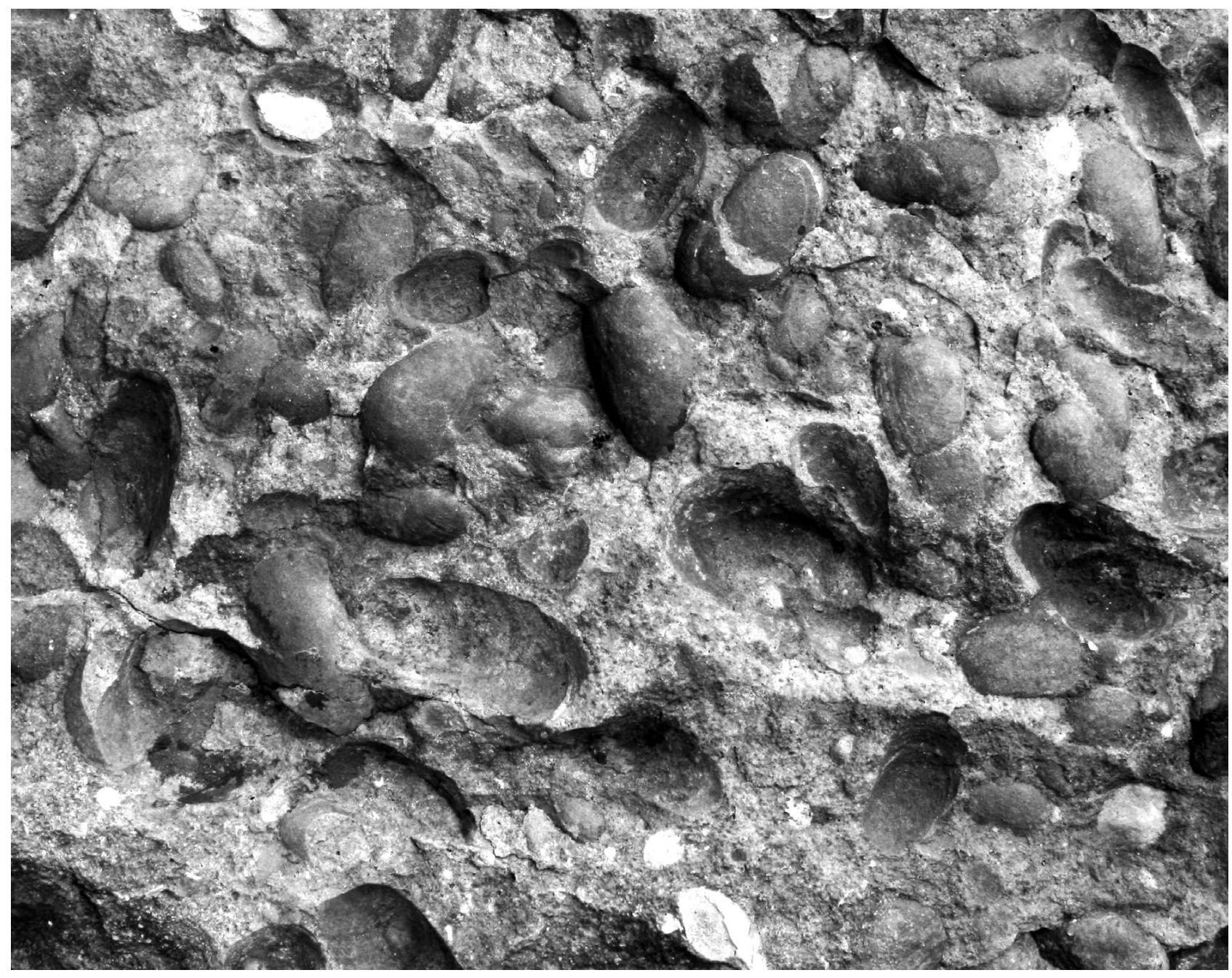

Figure 9. Bedding plane with Modiolopsis pragensis sp. nov., paratypes, coarse sandstones, Kosov Formation, Hirnantian, uppermost Ordovician, shallow syncline north of Praha-Běchovice, $\times 1.05$.

most Ordovician, together with Normalograptus persculptus (Elles \& Wood, 1907).

Type locality. - Bohemia, Praha-Běchovice, shallow syncline north of the village, temporary outcrops in the research institution's area (Marek 1963b).

Geographic distribution. - The Hirnantia sagittifera-Sluha kosoviensis Community is known only from the Prague Basin, Bohemia. It is analogous and homologous with the similar communities of the Hirnantia Community Group. It differs namely by its high diversity. In Bohemia it replaced the shallow water Modiolopsis pragensis Community dominated by infaunal elements after a moderate transgressive deepening of the sea (Havlíček 1982). Havlíček (1989) pointed out that the Hirnantia fauna of Bohemia and China, in spite of enormous distance, is closely similar and contains not only genera but also many species com- mon to both the regions. Abundant nuculoids, together with Pterinea? sp. were mentioned, and Praenucula sp. and Palaeoneilo sp. were figured from the Hirnantian of the Anti-Atlas, Morocco by Babin \& Destombes (1990). Indeterminable Hirnantian bivalves were mentioned in the lower Hirnantian as the part of the Hirnantia Association, in the higher Trematis-bivalve assemblages, and in the $\mathrm{Ho}$ lorhynchus Association of the Oslo-Asker area, Norway (Brenchley \& Cocks 1982).

Environment interpretation. - The Hirnantia sagittiferaSluha kosoviensis Community occurs in the flat lenses and nodules of light-grey decalcified slightly clayey compact siltstone, which forms the level in the ash-grey clayey micaceous shale. The bivalve community described herein (Table 1) is quite diversified (11 species of bivalves). The bivalves are mostly well preserved, not fragmented, mostly disarticulated (71.4\%) but also quite commonly preserved 
Table 1. Numerical and ranked abundance of bivalves in the Hirnantia sagittifer-Sluha kosoviensis Community, Uppermost Kosov Formation, late Hirnantian, uppermost Ordovician, Praha-Běchovice, shallow syncline north of the village, outcrops in the research institutions area, Bohemia (Marek 1963b). RV and LV = right and left valves (disarticulated); $\mathrm{A}=$ shells with conjoined valves; $\mathrm{RA}=$ percentage relative abundance; $\mathrm{AA}=$ percentage relative abundance of shells with conjoined valves; $\mathrm{R}=$ rank abundance.

\begin{tabular}{|c|c|c|c|c|c|c|c|}
\hline Species & Life habits & RV & LV & A & RA & AA & $\mathrm{R}$ \\
\hline Mytilarca mareki & semi-infaunal & 41 & 19 & 11 & 64.1 & 26.8 & 1 \\
\hline Sluha kosoviensis & infaunal & 8 & 5 & 1 & 11.7 & 13.3 & 2 \\
\hline Nuculites aff. planulatus & infaunal & 2 & 2 & 2 & 6.3 & 50.0 & 3 \\
\hline Praeleda compar & infaunal & - & 1 & 3 & 5.5 & 85.7 & 4 \\
\hline Praenucula abrupta & infaunal & 3 & 2 & - & 3.9 & - & 5 \\
\hline ?Sphenolium cf. parallelum & infaunal & - & 1 & 1 & 2.3 & 66.7 & 6 \\
\hline Myoplusia sp. & infaunal & 1 & 1 & - & 1.6 & - & 7 \\
\hline Praenucula dispar & infaunal & 1 & 1 & - & 1.6 & - & 8 \\
\hline Myoplusia obtusa & infaunal & - & - & 1 & 1.6 & 100.0 & 9 \\
\hline Myoplusia contrastans & infaunal & - & 1 & - & 0.8 & - & 10 \\
\hline Modiolopsis cf. pragensis & infaunal & 1 & - & - & 0.8 & - & 11 \\
\hline Totals & & 57 & 33 & 19 & $100.2 \%$ & $28.8 \%$ & \\
\hline
\end{tabular}

as shells with conjoined and articulated open valves $(28.8 \%)$. In the soft-bottom environment the abundant infaunal deposit-feeding nuculoid bivalves (33\%) occur; diversified group is represented by $67.5 \%$ disarticulated shells and by $32.5 \%$ shells with conjoined valves. The dominant ambonychiid Mytilarca mareki $(64.1 \%)$ was most probably semi-infaunal, byssate (percentage relative abundance of conjoined shells with conjoined valves is relatively high $-26.8 \%$ ).

The Recent nuculoids (Nuculacea and Nuculanacea) inhabit all types of soft substrates from the fine muddy sand or silt, muddy sands to clay, sandy gravel to clayey gravel rich in organic material and well ventilated (e.g., Yonge 1939, Davitašvili \& Merklin 1966). We suppose that the Hirnantia sagittifera-Sluha kosoviensis Community occupied the well-ventilated environment of the soft bottom silts with high organic content. The community was most probably autochthonous and with minimal transport. The idea is supported by the common preservation of the articulate brachiopods, semi-infaunal Mytilarca mareki and infaunal bivalves as shells with conjoined valves.

Hirnantia sagittifera-Sluha kosoviensis Community may be compared with the lower and middle Llandovery level bottom, non-reef Linoporella and DicoelosiaSkenidioides communities, Benthic Assemblage 3-4 life zone of Boucot (1975, cf. Havlíček \& Vaněk 1990). Ordovician silts in the Prague Basin were favoured by nuculoids. The most diversified community (27 nuculoid species) is known from the siltstones of the Zahorany Formation (late Sandbian). In general the nuculoids occur quite commonly in the Prague Basin Ordovician also in the well-ventilated claystone and sandy facies bottoms (Kříž 1997).

\section{Conclusions}

1. The Bivalvia dominated low diversity Modioliopsis pragensis Community occurs in the uppermost few metres of the high Hirnantian in the eastern part of the Prague Basin, Bohemia. It originated just at the end of the glaciation period when the sea level was still low due to locally tectonically uplifted bottom. The regressive Kosov Formation (Hirnantian) sequence culminated here by a shallow water, storm generated petromictic conglomerates and heavybedded shallow water sandstones.

2. The Hirnantia sagittifera-Sluha kosoviensis Community from the uppermost Hirnantian occurs in eastern part of the Prague Basin, Bohemia where it occupied a wellventilated quiet environment of the soft carbonate siltstone bottom during the uppermost Hirnantian transgression following the end of glaciation. It represents the most diversified known community of the Hirnantia Community Group in the World yet known.

3. In the uppermost Ordovician (Hirnantian) a total disappearance of barriers made possible faunal migrations between Perunica, Baltica and Avalonia (Havlíček et al. 1994) after global sea level rise at the end of the glaciation before the oceanic circulation stagnated at the base of the Silurian. The bivalves Mytilarca mareki and Metapalaeoneilo dromon sp. nov., support the possibility of migrations from the equatorial region of Baltica carbonate platforms to Perunica and the bivalves Nuculites aff. planulatus and ?Sphenolium cf. parallelum migrated probably from the equatorial regions of Avalonia and Laurentia. The Hirnantia sagittifera-Sluha kosoviensis Community fauna extended eastwards from Perunica to Central China (Rong \& Harper 1988, Sheehan 
2001). The same authors assign this fauna to the temperateto-subtropical zone of the Kosov Province (between $30^{\circ}$ to $45^{\circ} \mathrm{S}$ ). Perunica (Bohemia) placed on the continental reconstructions for the late Ordovician in circumpolar region at higher latitudes than $60^{\circ} \mathrm{S}$ (Torsvik 1998, Cope 2002) was according to our opinion probably at a lower latitude position.

4. Previous conclusions support the data of Havlíček et al. (1994), who situated the microcontinent Perunica close to Baltica in the lowermost Ordovician, drifted during the Ordovician and Silurian from high latitudes (Lower Ordovician - around $28^{\circ} \mathrm{S}$ ) in the southern hemisphere towards the palaeoequator (Lower Devonian - between 5-9 $\mathrm{S}$ ).

5. In the Hirnantian two pulses of the extinction occurred. During the beginning of the glaciation the sea level declined and the climatic gradient intensified. A second, short pulse of extinction came when the glaciation ended, sea level rose, and the climatic gradient lessened. Endemic faunas in epicontinental seas were especially hard hit in contrast to the biota in open marine settings (Droser \& Sheehan 1995, Sheehan 2001). Before end of the Hirnantian the evolution of the Hirnantia Community Group represents the evidence of the environment recovery during transgression following the glaciation. Further rapid rise of the sea level, together with the sedimentation of the euxinic facies of dark graptolitic shale at the base of the Silurian, represented drastic reduction in sedimentation rate with a lack of the sea bottom ventilation in open marine systems on a global scale, and caused extinction of the Hirnantia Community Group fauna.

\section{Acknowledgements}

We are indebted to Claude Babin, Université Claude Bernard, Lyon, John C. W. Cope, National Museum of Wales, Cardiff, and John Pojeta, Jr., U.S. Geological Survey, Washington, D.C., for valuable suggestions, constructive comments and linguistic improvement. Our special thanks are extended to the late Ladislav Marek from the Czech Academy of Sciences who in the period 1951 to 1962 discovered and collected the bivalves in the Kosov Formation from new localities in the vicinity of Praha-Běchovice and in other localities in the Prague Basin. One of the autors (J.K.) was prepared to describe the Hirantian Bivalvia together with him but he passed away before the our plans could be realized. Vojtěch Turek and Martin Valent, National Museum, Prague kindly provided access to the collections. We also thank to Štěpán Manda for his help with the digitalisation of the Prague Basin Hirnantian distribution map. The research was funded by the Czech Geological Survey, and by the Grant Agency, Charles University, Prague, Natural Sciences - Geosciences project No. 39908. Authors were also supported by the project $\mathrm{VaV}$ DE08P04OMG002. This paper is submitted as a contribution to the Czech Geological Survey, Prague Research Programme.

\section{References}

ADAMS, H. \& ADAMS, A. 1854-1858. The genera of Recent Mollusca arranged according to their organization. $661 \mathrm{pp}$. J. van Vorst, London.

BABIN, C. 1966. Mollusques Bivalves et Céphalopodes du Paléozoïque armoricain. 470 pp., 18 pls. Imprimerie Commerciale et Administrative, Brest.

BABIN, C. \& BEAUlieu, G. 2003. Les Mollusques Bivalves de l'Ordovicien de Saint-Clément-de-la-Place (Maine-et-Loire, sud-est du Massif Armoricain). Bulletin de la Société des sciences naturelles de l'Ouest de la France, nouvelle série 25(4), 177-206.

BABIN, C. \& Destombes, J. 1990. Les Mollusques Bivalves et Rostroconches ordoviciens de l'Anti-Atlas marocain: Intérêt paléogéographique de leur inventaire. Géologie Méditerranéenne 17(3-4), 243-261.

BABIN, C. \& GUTIÉRREZ-MARCO, J.C. 1991. Middle Ordovician Bivalves from Spain and their phyletic and palaeogeographic significance. Palaeontology 34(1), 109-147.

BABIN, C. \& HAMMAN, W. 2001. Une nouvelle espèce de Modiolopsis (Bivalvia) dans l'Arenig (Ordovicien inférieur) de Daroca (Aragon, Espagne); réflexions sur la denture des bivalves primitifs. Revista Española de Paleontología 16(2), 269-282.

BABIN, C. \& Melou, M. 1972. Mollusques Bivalves et Brachiopodes des "schistes de Raguenez " (Ordovicien supérieur du Finistère); conséquences stratigraphiques et paléobiogéographiques. Annales de la Société Géologique du Nord 92(2), 79-94.

BARRANDE, J. 1846. Notice préliminaire sur le systême et les Trilobites de Bohême. 97 pp. Leipsic.

BARRANDE, J. 1852. Systême silurien du centre de la Bohême. Trilobites 1. 935 pp., 51 pls. Prague \& Paris.

BARRANDE, J. 1881. Systême silurien du centre de la Bohême. Classe des Mollusques, ordre des Acéphalés 6. 342 pp., 356 pls. Prague \& Paris.

BASSLER, R. S. 1915. Bibliographic index of American and Silurian Fossils. United States National Museum Bulletin 92(2), 719-1521.

BEURLEN, K. 1944. Beiträge zur Stammesgeschichte der Muscheln. Sitzungsberichte. Bayerische Akademie der Wissenschaften, Mathematisch-Naturwissenschaftliche Klasse 1-2, 133-145.

BouCOT, A.J. 1975. Evolution and extinction rate controls. Developments in Palaeontology and Stratigraphy 1. 427 pp. Elsevier Scientific Publishing Company, Amsterdam.

BouCOT, A.J. \& KŘíž, J. 1999. Definition of the terms "homologous" and "analogous" community, 32. In BOUCOT, A.J. \& LAWSON, J.D. (eds) Paleocommunities: a case study from the Silurian and Lower Devonian, World and Regional Geology Series 11. xv +895 pp. Cambridge University Press, Cambridge.

BRADSHAW, M.A. 1971. The dentition and musculature of some Middle Ordovician (Llandeilo) bivalves from Finistère, France. Palaeontology 13(4), 623-645. 
BRAdSHAW, M.A. 1978. Position of soft parts in fossil palaeotaxodont bivalves as suggested by features of the shell interior. Alcheringa 2, 203-215.

DOI $10.1080 / 03115517808527777$

BRADSHAw, M.A. 1999. Lower Devonian bivalves from the Reefton Group, New Zealand. Association of Australasian Palaeontologists, Memoir 20, 1-171.

BRENCHLEY, P.J. \& COCKS, L.R.M. 1982. Ecological associations in a regressive sequence: the latest Ordovician of the Oslo-Asker District, Norway. Palaeontology 25(4), 783-815.

Brenchley, P.J., ROMANO, M., Young, T.P. \& ŠTORCH, P. 1991. Hirnantian glaciomarine diamictites - evidence for the spread of glaciation and its effects on Upper Ordovician faunas. In BARNES, C.B. \& WiLliams, S.H. (eds) Advances in Ordovician Geology, Geological Survey of Canada, Paper 90-9, 325-336.

BRENCHLEY, P.J. \& ŠTORCH, P. 1989. Environmental changes in the Hirnantian (upper Ordovician) of the Prague Basin, Czechoslovakia. Geological Journal 24, 161-181.

BRETSKY, S.S. \& BRETSKY, P.W. 1977. Morphological variability and change in the palaeotaxodont bivalve mollusk Nuculites planulatus (Upper Ordovician of Quebec). Journal of Paleontology 51(2), 256-271.

BRONGNIART, A. 1822. Les trilobites. In BRONGNIART, A. \& DESMAREST, A.G. Histoire naturelle des crustacés fossiles, sous les rapports zoologiques et géologiques. 65 pp. F.G. Levrault, Paris.

CARTER, J.G. 2001. Shell and ligament microstructure of selected Silurian and Recent palaeotaxodont (Mollusca: Bivalvia). American Malacological Bulletin 16, 217-238.

CONRAD, T.A. 1838. Report on the palaeontological department of the survey (of New York). New York Geological Survey Annual Report 2, 107-119.

CONRAD, T.A. 1841. Annual report of the paleontology of the State of New York. New York Geological Survey Annual Report 5, 25-57.

CONRAD, T.A. 1842. Observations on the Silurian and Devonian systems of the United States, with descriptions of new organic remains. Journal of the Academy of Natural Science of Philadelphia 8(2), 228-280.

Cope, J.C.W. 1997. The early phylogeny of the class Bivalvia. Palaeontology 40(3), 713-746.

CoPE, J.C.W. 1999. Midle Ordovician Bivalves from Mid- Wales and the Welsh Borderland. Palaeontology 42(3), 467-499. DOI 10.1111/1475-4983.00081

COPE, J.C.W. 2000. A new look at early bivalve phylogeny, 81-95. In HARPER, E.M., TAYLOR, J.D. \& CRAME, J.A. (eds) The evolutionary biology of Bivalvia. The Geological Society of London, Special Publication 177.

COPE, J.C.W. 2002. Diversification and biogeography of bivalves during the Ordovician Period, 25-52. In CRAME, J.A. \& OWEN, A.W. (eds) Palaeogeography and Biodiversity Change: the Ordovician and Mesozoic-Cenozoic Radiations. Geological Society of London, Special Publication 194.

COPE, J.C.W. 2005. Bivalve and rostroconch molluscs, 196-208. In WebBy, B.D., PARIS, F., Droser, M. \& PERCIVAL, I.G. (eds) The Great Ordovician Biodiversification Event. Columbia University Press, New York.

DALL, W.H. 1889. On the hinge of pelecypods and its development with an attempt toward a better subdivision of the group. American Journal of Sciences, Third Series 38 (228), 445-462.

DALMAN, J.W. 1828. Uppställning och Beskriftning af de i Sverige funne Terebratuliter. Kunglige Svenska Vetenskapsakkademiens Handlingar 1827, 85-155.

DAVITAŠVILI, L.Š. \& MERKLIN, R.L. 1966. Spravočnik po ekologii morskich dvustvorok. (Handbook on marine bivalves ecology). 349 pp. Nauka, Moskva.

DROSER, M.L. \& SHEEHAN, P.M. 1995. Paleontological significance of the Ordovician radiation and end Ordovician extinction: evidence from the Great Basin, 64-106. In COOPER, J.D. (ed.) Ordovician of the Great Basin: Fieldtrip guidebook and volume for the Seventh International Symposium on the Ordovician System. The Pacific Section Society for Sedimentary Geology (SEPM), Fullerton, California, USA.

ELlES, G.L. \& WoOD, E.M.R. 1907. A monograph of British graptolites. Palaeontographical Society Monographs 6(1907), 217-272.

FISCHER, P. 1880-1887. Manuel de conchyliologie et de paléontologie conchyliologique ou histoire naturelle des mollusques vivants et fossiles. 1880, pp. 1-112; 1881, pp. 113-304; 1882, pp. 305-416; 1883, pp. 417-608; 1884, pp. 609-688; 1885, pp. $689-896$; 1886, pp. 897-1008; 1887, pp. 1009-1369. F. Savy, Paris.

FOERSTE, A.F. 1914. Notes on the Lorraine faunas of New York and the province Quebec. Denison University Scientific Laboratories Bulletin 17, 247-339.

FucHS, A. 1919. Beitrag zur Kenntnis der Devon Fauna der Verse und Hobräcker Schichten des sauerländischen Faciesgebietes. Jahrbuch der Preussischen geologischen Landesanstalt 39(1918), 58-95.

GRAY, J.E. 1824. A natural arrangement of Mollusca, according to internal structure. Repository 15, 229-239.

GRAY, J.E. 1847. A list of the genera of Recent Mollusca, their synonyms and types. Proceedings of the Royal Zoological Society of London 15, 129-219.

GrobBEN, K. 1894. Zur Kenntniss der Morphologie, Verwandschaftsverhältnisse und des Systems der Mollusken. Sitzungsberichte der Kaiserlichen Akademie der Wissenschaften. Mathematisch-Naturwissenschaftliche Klasse 103, 61-86.

HALL, J. 1847. Natural History of New York. Paleontology. Vol. 1.338 pp., 88 pls. Geological Survey of New York, New York.

HALl, J. \& WhitFIELD, R.P. 1869. Preliminary notice of the lamellibranchiate shells of the Upper Helderberg, Hamilton and Chemung groups, with others from the Waverly sandstones, Part 2. $80 \mathrm{pp}$.

HAVLÍČEK, V. 1950. The geology of the Lower Paleozoic of Úvaly. Sborník Státního geologického ústavu Československé republiky, Oddíl geologický 17, 141-184. [in Czech]

HAVLÍČEK, V. 1976. Evolution of Ordovician brachiopod communities in the Mediterranean Province, 349-358. In BASSETT, M.G. (ed.) The Ordovician System: proceedings of a Palaeontological Association symposium, Birmingham, Sep- 
tember 1974. 696 pp. University of Wales Press \& National Museum of Wales, Cardiff.

HAVLÍČEK, V. 1977. Brachiopods of the Order Orthida in Czechoslovakia. Rozpravy Ústředního ústavu geologického 44, $1-327,56$ pls.

HAVLÍČEK, V. 1982. Ordovician in Bohemia: development of the Prague Basin and its benthic communities. Sborník geologických věd, Geologie 37, 193-136.

HAVlíčEK, V. 1987. Ordovician, 13-20. In STRAKA, J. (ed.) Explanation of the geological map ČSSR $1: 25$ 000, 12-244 Praha-east. 72 pp. Ústřední ústav geologický, Praha. [in Czech]

HAVLíčEK, V. 1989. Climatic changes and development of benthic communities through the Mediterranean Ordovician. Sborník geologických věd, Geologie 44, 79-116.

HAVLíčEK, V. 1994. Kosovian inarticulate brachiopods and their ancestors (Late Ordovician, Prague Basin). Věstník Českého geologického ústavu 69(1), 59-67.

HAVlíČEK, V. 1998. Ordovician, 41-79. In CHLUPÁČ, I., HAVlíČEK, V., KŘíž, J., KUKAL, Z. \& S̆TORCH, P. Paleozoic of the Barrandian (Cambrian to Devonian). 183 pp. Český geologický ústav, Praha.

HAVLÍČEK, V. \& VANĚK, J. 1990. Ordovician invertebrate communities in black-shale lithofacies (Prague Basin, Czechoslovakia). Věstník Českého geologického ústavu 65(4), 223-236.

HAVLÍČEK, V., VANĚK, J. \& FATKA, O. 1994. Perunica microcontinent in the Ordovician (its position within the Mediterranean Province, series division, benthic and pelagic associations). Sborník geologických věd, Geologie 46, 23-56.

IREDALE, T. 1924. Results from Roy Bell's Molluscan collections. Proceedings of Linnean Society of New South Wales 49, 179-278.

ISBERG, O. 1934. Studien über Lamellibranchiata des Leptaenakalkes in Dalarna. 493 pp. Håkan Ohlssons, Lund.

KOROBKOV, I.A. 1954. Handbook of Tertiary molluscs, bivalves. 444 pp. Gostoptex, Leningrad.

Kříž, J. 1969. Genus Butovicella Křiž, 1965 in the Silurian of Bohemia (Bivalvia). Journal of Geological Sciences, Palaeontology 10, 105-139.

KŘíž, J. 1997. Remarks on the paleoecology of the Prague Basin Ordovician Bivalvia. Zprávy o geologických výzkumech v roce 1996, 168-172. [in Czech]

KŘíž, J. 1999. Bivalvia dominated communities of Bohemian type from the Silurian and Lower Devonian carbonate facies, 229-252. In Boucot, A.J. \& LAwson, J.D. (eds) Final report, project Ecostratigraphy. Paleocommunities: A case study from the Silurian and Lower Devonian. 895 pp. Cambridge University Press, Cambridge.

KŘíž, J. 2008. A new bivalve community from the lower Ludlow of the Prague Basin (Perunica, Bohemia). Bulletin of Geosciences 83(3), 237-280.

DOI 10.3140/bull.geosci.2008.03.237

LAMCKE, K. 1934. Beitrag zur Kenntnis der Muschelfauna des obersilurischen Beyrichienkalkes. Zeitschrift für Geschiebeforschung 10, 185-199.

LESPÉRANCE, P.J. 1974. The Hirnantian fauna of the Percé Area
(Québec) and the Ordovician-Silurian boundary. American Journal of Science 274, 10-30.

LESPÉRANCE, P.J. \& SHEEHAN, P.M. 1976. Brachiopods from the Hirnantian stage (Ordovician-Silurian) at Percé, Québec. Palaeontology 19(4), 719-731.

LILJEDAHL, L. 1994. Silurian nuculoid and modiomorphid bivalves from Sweden. Fossils and Strata 33, 1-89.

LINNÉ, C. 1758. Systema naturae per regna tria naturae, secundum classes, ordines, genera, species, cum characteribus, differentiis, synonymis, locis. Editio decima, reformata. 824 pp. Holmiae.

MAREK, L. 1951. Nové nálezy ve vrstvách kosovských $\left(\mathrm{d} \xi_{2}\right)$. Sborník Ústředního ústavu geologického $k$ šedesátinám prof. Radima Kettnera 18, 233-244.

MAREK, L. 1963a. Bellerophontid gastropods in the Kosov Beds (Ordovician) of Bohemia. Věstník Ústředního ústavu geologického 38, 273-276.

MAREK, L. 1963b. Research of the Kosov Formation fauna, Bohemian Ordovician. Zprávy o geologických výzkumech v roce 1962, 103-104. [in Czech]

MAREK, L. \& HAVLÍČEK, V. 1967. The articulate brachiopods of the Kosov Formation (Upper Ashgillian). Věstník Ústředního ústavu geologického 42(4), 275-284.

MCALESTER, A.L. 1968. Type species of Paleozoic nuculoid bivalve genera. Memoir of the Geological Society of America 105, 1-143.

MCALESTER, A.L. 1969. Palaeotaxodonta (Bivalvia), N227-N243. In MOORE, R.C. (ed.) Treatise on Invertebrate Paleontology. Part N, Mollusca 6, Bivalvia. 487 pp. Geological Society of America \& University of Kansas Press, Boulder $\&$ Lawrence.

MERGL, M. 1986. Craniopsidae (Inarticulata, Brachiopoda) in the Ordovician-Silurian sequence of the Prague Basin (Bohemia). Věstník Ústředního ústavu geologického 61(3), 183-186.

MIKULÁŠ, R. 1992. Trace fossils from the Kosov Formation of the Bohemian Upper Ordovician. Sborník geologických věd, Palaeontologie 32, 9-54.

MILlER, S.A. 1877. The American Palaeozoic fossils, a catalogue of the genera and species. $253 \mathrm{pp}$. Published by the author, Cincinnati, Ohio.

MILLER, S.A. 1881. Description of five new species of Silurian fossils, and remarks upon an undetermined form. The Journal of the Cincinnati Society of Natural History 3(4), 314-317.

MILLER, S.A. 1889. North American geology and palaeontology. 664 pp. Published by the author, Cincinnati, Ohio.

MUNIER-CHALMAS, E.C.P.A. 1876. Mollusques nouveaux des terrains paléozoïques des environs de Rennes. Journal de Conchyliologie 24(3),16, 102-109.

NeUmAYR, M. 1884. Zur Morphologie der Bivalvenschlosses. Sitzungsberichte der Kaiserlichen Akademie der Wissenschaften, Mathematisch-naturwissenschaftliche Klasse 88(2), 385-419.

NeumayR, M. 1891. Beiträge zu einer morphologischen Eintheilung der Bivalven. Denkschriften der Kaiserlichen Akademie der Wissenschaften, Mathematisch-naturwissenschaftliche Klasse 58, 701-801. 
NewELl, N.D. 1969. Subclass Anomalodesmata Dall, 1889, N818. In MoORE, R.C. (ed.) Treatise on Invertebrate Paleontology. Part N, Mollusca 6, Bivalvia. 487 pp. Geological Society of America \& University of Kansas Press, Boulder \& Lawrence.

PERNER, J. 1903. Systême silurien du centre de la Bohême. Gastéropodes 4(1). 164 pp., 89 pls. Prague \& Paris.

PFAB, L. 1934. Revision der Taxodonta des böhmischen Silurs. Palaeontographica, Abteilung A 80, 195-253.

PoJETA, J., Jr. 1966. North American Ambonychiidae (Pelecypoda) Palaeontographica Americana 5(36), 131-241.

POJETA, J., JR. 1971. Review of Ordovician Pelecypods. U.S. Geological Survey Professional Paper 695, 1-46, 20 pls.

POJETA, J., JR. 1978. The origin and early taxonomic diversification of pelecypods. Philosophical Transactions of the Royal Society of London B 284, 225-246. DOI 10.1098/rstb.1978.0065

POJETA, J., Jr. \& STOTT, C.A. 2007. Nucularcidae: a new family of palaeotaxodont Ordovician pelecypods (Mollusca) from North America and Australia. Canadian Journal of Earth Science 44, 1479-1501. DOI 10.1139/E07-028

PORTLOCK, J.E. 1843. Report on the geology of the county Londonderry, and parts of Tyrone and Fermanagh. xxi, 784 pp., 38 pls, A-I, map. Dublin \& London.

PRANTL, F. \& PřiBYL, A. 1944. Př́spěvek k poznání geologických poměrů u Tachlovic. Rozpravy České akademie věd a umění, Tř́ida II 54(3), 1-11.

RONG, JIA-YU \& HARPER, D.A.T. 1988. A global synthesis of the latest Ordovician Hirnantian brachiopod faunas. Transactions of the Royal Society of Edinburgh, Earth Sciences 79, 383-402.

RŮŽIČKA, B. \& PRANTL, F. 1961. Note on the determination of taxa of fossil pelecypods. Časopis Národního musea v Praze, Oddíl přirodovědný 130(1), 81-82. [in Czech]

SÁNCHEZ, T.M. 1990. Bivalvos del Ordovícico-Tardio de la Precordillera de San Juan (Argentina). Ameghiniana (Revista de la Asociación Paleontológica Argentina) 27(3-4), 251-261.

SHARPE, D. 1853. Description of the new species of Zoophyta and Mollusca, 146-158, Appendix B. In RIBEIRO, C., SHARPE, D. \& JONES, T.R. On the Carboniferous and Silurian formations in the neighbourhood of Bussaco, Portugal. Quarterly Journal of the Geological Society of London 9, 135-161.

SHEEHAN, P.M. 2001. The late Ordovician mass extinction. Annual Review of the Earth and Planetary Sciences 29, 331-364. DOI 10.1146/annurev.earth.29.1.331

STRAKA, J. ed. 1987. Explanation of the geological map ČSSR 1 : 25 000, 12-244 Praha-east. 72 pp. Ústřední ústav geologický, Praha. [in Czech]

SYSTEMATICS ASSOCIATION COMMITTEE FOR DESCRIPTIVE BIOLOGICAL TERMINOLOGY 1962. Terminology of simple symmetrical plane shapes, Chart 1a. Taxon 11, 145-156, 245-247.

ŠNAJDR, M. 1987. New odontopleurid trilobite from the Kosov
Formation (Ashgill, Bohemia). Časopis pro mineralogii a geologii 32(3), 303-304.

ŠTORCH, P. 1980. Litologický vývoj a biostratigrafie želkovického souvrství v jv. kř́dle Barrandienu. Manuscript, Geofond, Praha.

ŠTORCH, P. 1982. Ordovician-Silurian boundary in the northernmost part of the Prague Basin (Barrandian, Bohemia). Věstník Ústředního ústavu geologického 57(4), 231-236.

ŠTORCH, P. 1986a. Ordovician-Silurian boundary event in Bohemia (Prague Basin - Barrandian area). Lecture Notes in Earth Sciences, Global Bio-Events 8, 133-138.

ŠTORCH, P. 1986b. Ordovician-Silurian boundary in the Prague Basin (Barrandian area, Bohemia). Sborník geologických věd, Geologie 41, 69-103.

ŠTORCH, P. 1988. The Ordovician-Silurian boundary in the Prague Basin, Bohemia. Bulletin of the British Museum (Natural History), Geology 43, 95-100.

ŠTORCH, P. 1990. Upper Ordovician-lower Silurian sequences of the Bohemian Massif, central Europe. Geological Magazine 127(3), 225-239. DOI 10.1017/S0016756800014503

ŠTORCH, P. 2006. Facies development, depositional settings and sequence stratigraphy across the Ordovician-Silurian boundary: a new perspective from the Barrandian area of the Czech Republic. Geological Journal 41, 163-192.

DOI $10.1002 / \mathrm{gj} .1038$

ŠTORCH, P. \& LOYDELL, D.K. 1996. The Hirnantian graptolites Normalograptus persculptus and "Glyptograptus" bohemicus: Stratigraphical consequences of their synonymy. Palaeontology 39(4), 869-881.

TEMPLE, J.T. 1965. Upper Ordovician brachiopods from Poland and Britain. Acta Palaeontologica Polonica 10(3), 379-427, $21 \mathrm{pls}$.

TORSVIK, T.H. 1998. Palaeozoic palaeogeography: A North Atlantic viewpoint. GGF 120, 109-118.

TUNNICLIFF, S.P. 1982. A revision of late Ordovician bivalves from Pomeroy, Co. Tyrone, Ireland. Palaeontology 25(1), 43-88.

ULRICH, E.O. 1892. New Lamellibranchiata. American Geologist 10, 96-104, pl. 7.

ULRICH, E.O. 1894. The Lower Silurian Lamellibranchiata of Minnesota, from Volume 3. Final Report of the Geological and Natural History Survey of Minnesota, 475-628, pl. 35-42. (Published and distributed under separate cover prior to publication of the entire Volume 3 in 1897.)

WALKER, K.R. \& BAMBACH, R.K. 1974. Analysis of communities, 1-20. In ZIEGLER, A.M., WALKER, K.R., ANDERSON, E.J., KAUFFMAN, E.G., GINSBURG, R.N. \& JAMES, N.P. (eds) Principles of benthic community analysis. Notes for a Short Course. Sedimenta IV: Publications of the Comparative Sedimentology Laboratory. 168 pp. The University of Miami, Coral Gables, Florida.

YongE, C.M. 1939. The protobranchiate mollusca; a functional interpretation of their structure and evolution. Philosophical Transactions of the Royal Society of London, Series B 230(566), 79-147. DOI 10.1098/rstb.1939.0005 